\title{
UNIVERSITY OF CINCINNATI
}

\section{Date: October 12, 2007}

I,

Kathryn E. Easterday

hereby submit this work as part of the requirements for the degree of:

Doctor of Philosophy

in:

Business Administration

\section{It is entitled:}

An Examination of the Link Between January Returns and Contemporaneous Earnings: Is the Small Firm/January Effect an Economically Relevant Phenomenon?

This work and its defense approved by:

Chair: Jens A. Stephan

Davit Adut

Martin S. Levy

P.K. Sen 
An Examination of the Link between January Returns and Contemporaneous Earnings: Is the Small Firm/January Effect an Economically Relevant Phenomenon?

By

Kathryn E. Easterday

BS, University of Cincinnati

MS, Kettering University

MAcc, Wright State University

\section{A DISSERTATION}

Submitted to the

Department of Accounting,

College of Business,

University of Cincinnati

in partial fulfillment of the requirements

for the degree of

DOCTOR OF PHILOSOPHY

Committee Chair: Jens A. Stephan, PhD

October 2007 


\begin{abstract}
This paper explores the economic relevance of the small firm/January effect by examining whether small-firm January returns are positively correlated with contemporaneous accounting earnings. Employing an empirical specification derived from the returns-earnings model set forth by Ohlson (1995) and Feltham and Ohlson (1995), this paper provides evidence that for the second, third and fourth quarters associations between the quarter's first-month returns and the corresponding quarterly earnings are significantly positive. In contrast, the relationship between January returns and first quarter earnings is significantly negative. A novel sample partition which separates small firms that do not experience a January effect from those that do shows that only "January effect" firms exhibit this curious negative relationship between returns and earnings. Results are robust to alternative model specifications. Evidence that January returns are not positively related to contemporaneous accounting earnings calls into question the economic relevance of this market anomaly.
\end{abstract}


Copyright by

Kathryn E. Easterday

2007 


\section{Acknowledgements}

Family and friends provided a great deal of encouragement and assistance during the course of my PhD program. My husband Dennis somehow maintained both his sanity and mine through the entire journey. Words cannot express how much his love and support have meant.

I am grateful for the financial support of the Kelly Siddall Fellowship, the University Distinguished Graduate Fellowship and a University Graduate Scholarship from the University of Cincinnati.

This dissertation would not have been possible without the guidance and encouragement of my dissertation committee: Jens A. Stephan, PhD (Chair); Davit Adut, PhD; Martin S. Levy, PhD; and P.K. Sen, PhD. Their insightful comments and helpful advice saved me from many pitfalls along the way. James Deddens, PhD, graciously provided computer programming advice. Many thanks also to Linda Matuszewski, PhD and to Maef Woods, Mary Mindak, Anthony Holder and workshop participants at the University of Cincinnati and Miami University for comments and discussions regarding this paper. All errors are my own. 


\section{Table of Contents}

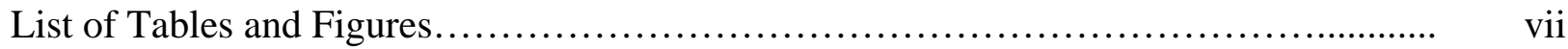

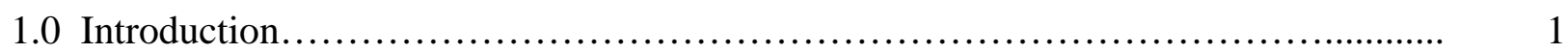

2.0 Background........................................................... 6

2.1 January returns and small firms........................................ 6

2.2 Returns, earnings and other information....................................... 8

3.0 Empirical specifications of Ohlson's (1995) valuation model....................... 12

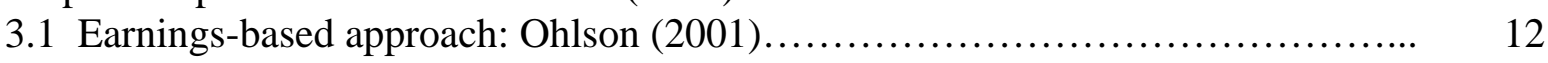

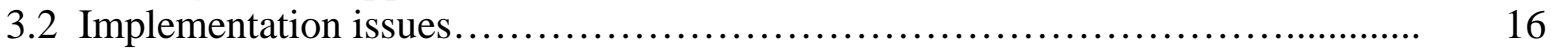

3.2.1 Beginning-of-period dates for price deflators.......................... 16

3.2.2 Availability of analysts' forecasts for small firms........................ 17

3.2.3 General regression specification based on Ohlson (2001)................. 18

3.3 Book value as a conditioning variable: Penman and Yehuda (2006)............... 19

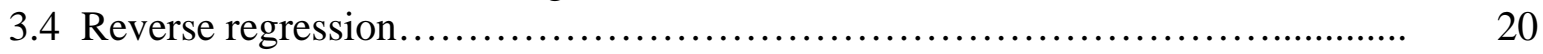

3.5 Coefficient predictions............................................... 21

4.0 Research design........................................................ 24

4.1 "Contemporaneous" returns and earnings................................. 24

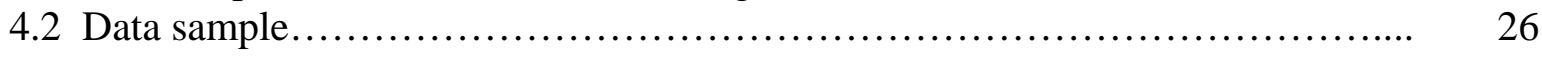

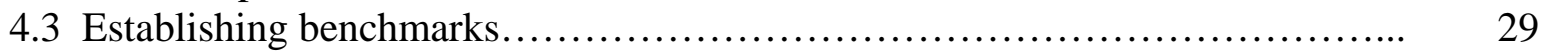

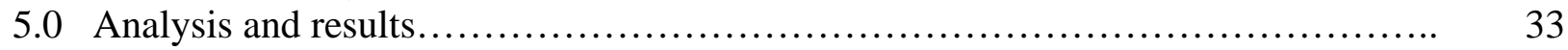

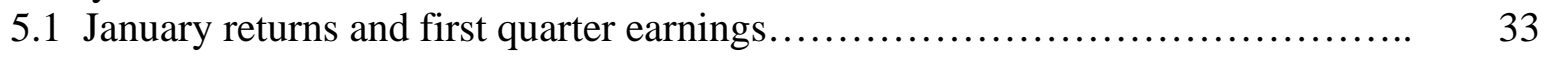

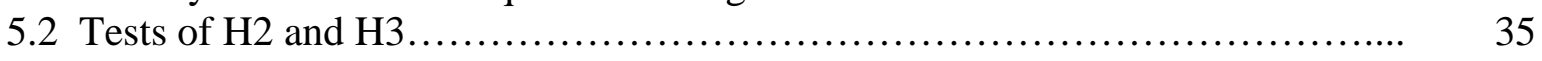

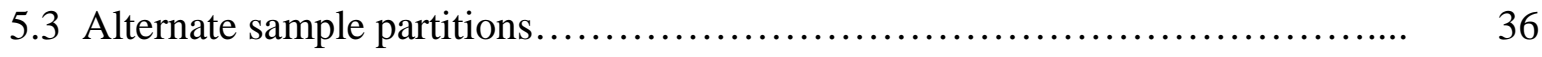

6.0 Robustness checks..................................................... 39

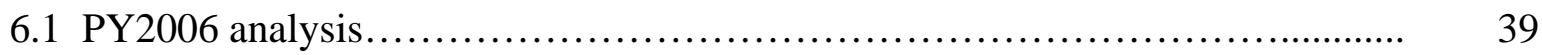

6.2 Reverse regressions.................................................. 42

7.0 Summary and conclusions............................................. 43

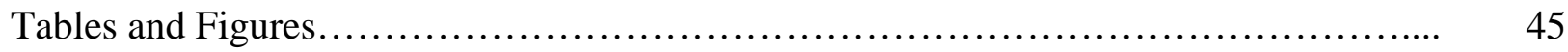

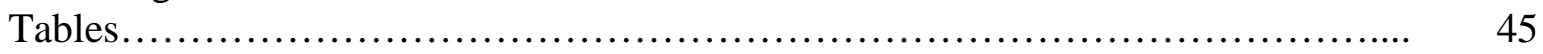

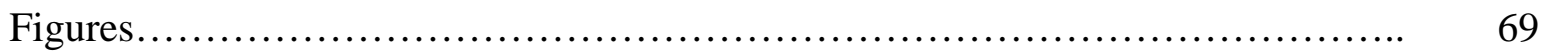

Appendices.............................................................. 72

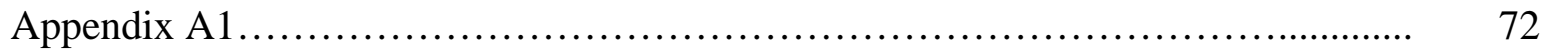

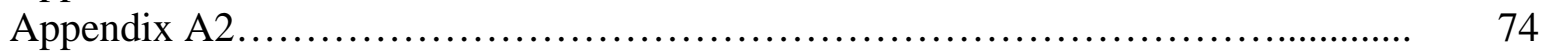

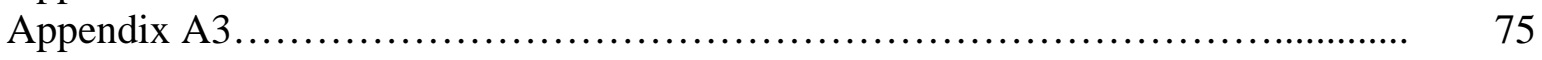

References............................................................ 76 


\section{List of Tables and Figures}

Table 1 Median firm size (\$MM) and number of firms by quintile and year in the full sample.

Table 2 Full sample summary statistics: Mean, standard deviation, and quartile values....................................................... 45

Table $3 \quad$ Firm size effect: mean January return in each quintile................... 47

Table 4 FM regressions of annual holding returns on contemporaneous annual earnings levels and changes..........................................

Table 5 FM regressions of quarterly holding returns on contemporaneous quarterly earnings levels and changes, all four quarters combined.................. 50

Table 6 FM coefficients from benchmark testing of returns-earnings association for quarters two, three and four......

Table 7 Mean FM coefficients for January (first quarter) returns and first quarter earnings.

Table 8 Paired t-tests to determine significance of differences between FM coefficients in Table 7 across all four quarters...........................

Table 9 Mean coefficients for FM regressions of holding returns for the last 2 months of each quarter and quarterly earnings..........................

Table 10 Mean FM coefficients from regressing January returns in year $(t)$ on annual and fourth-quarter earnings from year $(t-1)$

Table 11 Summary statistics for the full sample, partitioned according to January effect (JE) firms and non-January effect (NJE) firms

Table 12 Comparison of JE firms to NJE firms for regression of January returns on first-quarter earnings using FM regression methodology.

Table 13 Robustness tests using book value as a conditioning variable in regressions of first-month returns on quarterly earnings...............................

Table 14 Reverse regression analysis of the association of earnings with monthly components of contemporaneous annual returns.

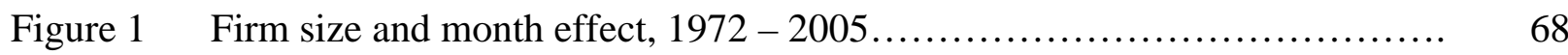

Figure 2 Time series of mean January returns for quintile 1 firms, 1972 - 2005.........

Figure 3 Distribution of JE and NJE firms across 100 annual subsets of firm size (“percentiles”). 


\subsection{Introduction}

Fama (1998) argues that many so-called market anomalies are tenuous in the sense that they are sensitive to the methodologies used to detect or measure them. Far from being tenuous, the small firm/January effect persists in defiance of economic theory which says it should be arbitraged away and has stubbornly survived over 60 years of varied empirical approaches by researchers seeking to characterize and explain it. Although its cause has remained a puzzle since it first emerged in capital markets literature, the anomaly appears to be more than a mere methodological or statistical aberration. This paper explores the economic relevance of the small firm/January effect by examining whether January returns are positively correlated with contemporaneous earnings, and thus behave in a manner that is both economically rational and consistent with accounting theory.

Several papers in the accounting literature form the foundation upon which the current investigation is built: Beaver et al. (1980), Collins et al. (1987) and Collins and Kothari (1989) all demonstrate a positive association between annual returns and earnings changes over the same period; Easton and Harris (1991) and Easton et al. (1992) show that both earnings levels and earnings changes are associated with contemporaneous annual returns. Warfield and Wild (1992) and Elliott and Hanna (1996) find that quarterly returns are positively associated with contemporaneous quarterly earnings, although correlations are generally weaker than for annual return-earnings associations. Event studies conducted on the information content of earnings observe positive correlations between quarterly returns and earnings variables (Bernard and Thomas 1989; Easton and Zmijewski 1989; Penman 1987). All of these results are consistent with the Ohlson (1995) and Feltham and Ohlson (1995) framework characterizing the relation between firm value, accounting data and other value-relevant information. 
The primary object of this inquiry is January returns, for which no corresponding monthly earnings data exists. Earnings data of the first quarter is the closest available temporal match but there is little precedent in the literature for analyzing the association between first-month returns and earnings of the same quarter. Easton and Zmijewski's (1989) study of cross-sectional variation in earnings response coefficients uses a 120-day event window which includes the last two months of the earnings quarter and the first two months of the announcement quarter. Penman's (1987) investigation of good news/bad news timing for quarterly earnings announcements examines the associations between returns in the first two weeks of quarter $t$ and earnings for quarter $t-1$ that are announced during quarter $t .^{1}$

After deriving an empirical specification of the analytical framework of Ohlson (1995) and Feltham and Ohlson (1995) which incorporates a recommendation set forth in Ohlson (2001) for capturing earnings expectations, I show that for the second, third and fourth quarters the associations between the quarter's first month (that is, April, July and October) returns and the corresponding quarterly earnings are significantly positive. In contrast, for January returns and first quarter earnings the coefficient is significantly negative in a one-tail test. I also find that January returns are negatively and significantly associated with earnings of the previous quarter and year. My research complements Penman (1987) by testing the effect of the small firm/January effect phenomenon on the association between returns and quarterly earnings without relying on an ex-post categorization of earnings as "good news" or "bad news."

As a check on the robustness of my results, an alternate specification of the returns-earnings association proposed by Penman and Yehuda (2006) in which the regression's independent variables include a balance sheet component - beginning-of-period book value - along with

\footnotetext{
${ }^{1}$ It is worth noting that Penman (1987) appears to acknowledge a potentially distorting effect of January returns in first quarter data and focuses the analysis on the other three quarters of the year.
} 
earnings level, is also adapted and tested. Consistent with their results for annual variables, my investigation reveals positive correlations between beginning-of-period book values and quarterly earnings in quarters one, two and three; a negative correlation in the fourth quarter is not significantly different from zero. The regression coefficients on earnings in this specification are significantly positive for the second, third and fourth quarters. But again, a positive association between returns in the month of January and first-quarter earnings is absent.

In summary, using two different model specifications I find significantly positive associations between first-month returns and quarterly earnings for the second, third and fourth quarters, but not for January returns and first-quarter earnings.

I also present evidence that the January effect is not universal among small firms by partitioning the sample between small firms whose January returns are larger than the mean return for the months of February through December (designated as "January effect" firms) and small firms whose January returns are not. The January effect occurs in only $62 \%$ of small firms. Performing returns-earnings regressions on the partitioned sample achieves interesting results: the first quarter earnings coefficient for small "January effect" firms is significantly negative for January returns in the primary regression, but for "non-January effect" firms there is a significantly positive coefficient on first-quarter earnings. In other words, firms that do not exhibit the January effect do show evidence of returns-earnings associations in the first quarter that are consistent with results for the rest of the calendar year. Under the alternate model specification, with book value as a conditioning variable on earnings, the results of this partition are ambiguous: the earnings coefficient is negative but not significantly different from zero for both "January effect" and "non-January effect" firms. 
The models and regression analyses discussed above are standard regressions with returns as the dependent variable. Both Beaver et al. (1987) and Collins and Kothari (1989) use reverse regression with returns as the independent variable to address the issue raised by Ryan (1986; 1988)of measurement error in earnings. In a supplemental analysis I follow the suggestion of Beaver et al. (1987) and use reverse regression to analyze the association between earnings and monthly components of quarterly returns. Once again, January is the nonconformist as it is the only month in which the association between earnings and returns is not significantly positive.

The research makes three contributions to accounting literature. First, this paper is the first to consider whether small firm January returns evolve in an economically rational manner by systematically exploring the association between January effect returns and contemporaneous accounting earnings. Evidence of a negative association between January returns and first quarter earnings is quite curious in light of previous theoretical and empirical results of a positive relationship between returns and earnings, and my findings are robust to alternate modes of analysis.

Second, partitioning the sample between firms that exhibit the January effect and firms that do not is an innovation that offers a more precise inquiry into the nature of the January anomaly. Results of the primary model specification indicate a clear departure in the nature of the returnsearnings association between the two firm types, suggesting that controlling for this firm characteristic may be important.

Finally, by examining associations between returns for the first month of a quarter and that quarter's earnings this paper expands the concept of "contemporaneous" returns and earnings and also shows that for the full sample a positive association between the two exists for all quarters except the first. Partitioning the sample shows that it is the January effect firms that 
appear to drive a disconnect in the positive association between returns and earnings for the first quarter.

This investigation yields a richer characterization of the small firm/January effect, even though the source and persistence of the anomaly is not well understood. The results documented here offer tantalizing evidence that the January effect anomaly involves a subset of small firms, and the returns of those firms do not appear to be consistent with their performance. Overall, the evidence that January returns are not positively related to contemporaneous accounting earnings may call into question the economic relevance of the phenomenon.

The study proceeds as follows. Section 2 is a review of literature relevant to the areas of the January effect and the association between returns and earnings. Section 3 provides a discussion of the primary and alternative model specifications used in the study. Section 4 contains the research design. Analysis and results are in Section 5. Section 6 describes robustness testing. Section 7 concludes. 


\subsection{Background}

\subsection{January returns and small firms}

Seasonal behavior of returns in US capital markets is documented as far back as 1904 (Rozeff and Kinney 1976; Wachtel 1942), and recent studies (Brown and Luo 2006; Easterday et al. 2007; Haug and Hirschey 2006) offer evidence that the January effect persists in modern US capital markets. Keim (1983) establishes the link between firm size and the magnitude of January returns, finding that January excess returns for small firms are larger than in other months and decrease monotonically with firm size, while February through December excess returns are relatively flat across all firm sizes. An opportunity to capture abnormal returns should be arbitraged away in an informationally efficient market, yet the small firm/January effect persists. $^{2}$

Numerous studies seek to provide an economic rationale for this seasonal increase in small firm returns. Tax management behavior is probably the most generally accepted rationale: investors sell off losing stocks at the end of the year to take advantage of capital losses for tax purposes, depressing prices which then rebound after the turn of the year (Branch 1977; Dyl 1977; Grinblatt and Keloharju 2004; Jones et al. 1991). More recent studies in this literature stream focus on differences in tax rules between individual and institutional investors, finding that high returns of small firms in January are more consistent with behaviors of tax-motivated individual investors than with "window-dressing" actions of institutional investment managers (Sias and Starks 1997; Poterba and Weisbenner 2001; Eakins and Sewell 1993).

\footnotetext{
${ }^{2}$ Using the magnitude of the January effect in the years between 1963 and 1979 as a benchmark, Mehdian and Perry (2002), Gu (2003) and Schwert (2003) offer evidence that the January effect declines or disappears after 1980.

However, studies using individual firm data to capture the joint effect of firm size described by Keim (1983), as well as longer time periods of study (Brown and Luo 2006; Easterday et al. 2007; Haug and Hirschey 2006; Haugen and Jorion 1996), find that the anomaly persists and is not declining in magnitude.
} 
There are substantial questions about whether tax-minimizing behavior by itself is enough to drive the January effect. Brown et al. (1983) find evidence of elevated January returns in the Australian stock market despite the fact that the Australian tax year extends from July to June rather than from January to December. Reinganum (1983) concludes that tax-loss selling does not entirely explain the January effect because prior year winner firms in his sample also exhibit high January returns, as do the loser firms most likely to be candidates for tax-loss selling. Similarly, Sias and Starks (1997) find high January returns for individual investor-dominated small firms whether the firms were winners or losers during the preceding year. Ritter (1988) and Ritter and Chopra (1989) find evidence that year-end portfolio rebalancing activities by small investors, not necessarily driven by tax-loss selling, are associated with high January returns for small firms. Fountas and Segredakis (2002) find little evidence supporting a tax management explanation for seasonality of returns in emerging world markets. All of these findings raise the possibility that the January effect in US markets may be coincidental to, not caused by, investors' tax management behavior.

Individual firm characteristics such as liquidity or default risk (Kramer 1994; Ligon 1997) and macroeconomic factors such as interest rates, inflation and consumption (Kramer 1994; Ligon 1997) have also been tested as possible explanations for the January effect. There is also some evidence that January returns may have predictive power for future returns (Brown and Luo 2006; McConnell et al. 2005).

Kross and Schroeder (1990) find evidence that for small firms, price responses to announcements of fourth-quarter earnings are of less magnitude than price responses to the earnings announcement of other quarters. The sample is very small and the investigation tests a theory that seasonality in price response to quarterly earnings announcements is related to 
differences in audit approach for small firms vs. large firms. Lu and Ma (2003) propose that high January returns are a reaction to positive earnings surprises in annual earnings announcements for the previous year that take place during that month. Their evidence is consistent with Penman's (1987) suggestion that seasonal behavior in returns of the second through fourth quarters may be linked to timing of good news vs. bad news in earnings announcements.

In summary, empirical evidence with regard to the small firm/January effect is mixed and to date none of the proposed explanations provide a satisfactory explanation for both the persistence and magnitude of the anomaly.

\subsection{Returns, earnings and other information}

Early accounting literature establishes a meaningful role for accounting information in capital markets by showing that prices are related to information in earnings reports (Ball and Brown 1968; Beaver 1968). The success of these efforts together with the introduction in (Fama et al. 1969) of event-study methodology, led to tests of numerous efficient markets hypotheses, ${ }^{3}$ including research into the speed of price reactions to information in earnings announcements (Francis et al. 1992; Patell and Wolfson 1984; and others). This reactive nature of price to earnings information is the basis for Penman (1987), which documents a tendency for quarterly earnings reports released early in the following quarter to be "good news." It is also the basis for $\mathrm{Lu}$ and $\mathrm{Ma}$ (2003), who find evidence that annual earnings announcements occurring in January are predominantly positive; as well as for Kross and Schroeder (1990), who posit that auditors' monitoring affects the precision of quarterly earnings numbers.

\footnotetext{
${ }^{3}$ See Fama (1991) for a detailed discussion of EMH tests in capital markets literature.
} 
Beaver et al. (1980) demonstrated the ability of prices to lead earnings rather than merely reacting to information in earnings announcements, prompting a shift in the literature to association studies of returns and earnings. Ryan (1986) argues that the true variable of interest with respect to valuation is permanent earnings, and the use of accrual accounting earnings to represent (unobservable) permanent earnings introduces measurement error into the regressions. Beaver et al. (1987) and Collins and Kothari (1989) provide evidence that the technique of reverse regression - in which earnings is the dependent variable, causing earnings measurement variations to be assigned to the regression error term - yields the same inferences as regressions of returns on earnings, with the added benefit of offering an opportunity for including additional independent variables (including lagged pricing terms) that may explain earnings.

Price incorporates all available value-relevant information but the information appears in accounting earnings with a lag (Easton 1999; Ryan 1986). Thus, proper alignment of returns and earnings periods is important in the regression. Collins et al. (1987) offer empirical evidence implying that the start of the returns period should precede the start of the earnings period because value-relevant information appears in price before earnings. Easton et al. (1992) show that lengthening the time period over which both returns and contemporaneous earnings are measured mitigates what Ryan $(1986 ; 1988)$ terms the "measurement error in earnings" that occurs due to accrual accounting, which gives rise to a lag between the capture of value relevant information in price and its appearance in accounting earnings. This may explain why the bulk of empirical returns-earnings association research uses annual time periods rather than quarterly. ${ }^{4}$ Adding an additional independent variable representing earnings of future periods is yet another approach to resolving the delay of information appearing in accounting numbers (Warfield and Wild 1992).

\footnotetext{
${ }^{4}$ Bernard and Thomas (1989), Easton and Zmijewski (1989), and Penman (1987) are notable exceptions.
} 
The response coefficient in the returns-earnings regression has also been examined extensively in empirical literature. Collins and Kothari (1989) show that response coefficients may be affected temporally by market factors such as the risk free rate. Firm-specific characteristics such as size (Collins et al. 1987; Easton and Zmijewski 1989; Freeman 1987), growth opportunities and earnings persistence (Collins and Kothari 1989; Easton and Zmijewski 1989) are shown to be cross-sectional determinants of response coefficients. Both Collins and Kothari (1989) and Collins et al. (1987) find that earnings response coefficients and adjusted $\mathrm{R}^{2}$ values increase as firm size increases. Their interpretation of these findings is that larger firms have richer information environments, with prices for larger firms capturing information in earnings earlier and more completely than for small firms.

The appropriate earnings variable(s) in the returns-earnings regression was a contentious issue from the start. Based on the theory that changes in price come from changes in expectations for future earnings, researchers sought ways to represent unexpected earnings as the explanatory variable for returns. Depending on the assumption for earnings evolution over time, either earnings level (purely transitory) or earnings change (purely permanent) may denote unexpected earnings. Regression specifications employing earnings changes (Beaver et al. 1980; Beaver et al. 1987; Collins and Kothari 1989; Collins et al. 1987) or earnings levels alone (Ali and Zarowin 1992) yield satisfactory results. However, both variables together explain returns better than either individually, although the earnings change association with returns may be weaker (Easton and Harris 1991; Easton et al. 1992; Kothari and Sloan 1992). Ohlson and Shroff (1992) argue that the existence of other value-relevant information beyond that contained in earnings and dividends suggests that the minimum variance earnings variable best characterizes unexpected earnings, and recommend using the residual from regressing earnings 
on earnings predictors. Other value-relevant information not included in earnings may also be proxied by analysts' forecasts, which are generally accepted in accounting literature as an effective empirical method for forecasting future earnings due to analysts' abilities to incorporate value-relevant forward-looking information (Brown and Rozeff 1978; O'Brien 1988; Rozeff 1983). See Beaver (2002) and Kothari (2001) for additional discussions of the early empirical earnings-returns research, as well as Brown (1993) and Kothari (2001) for comprehensive reviews of the earnings forecast literature.

Empirical findings supporting the use of both earnings level and earnings change variables in regressions of returns and earnings are consistent with the theoretical characterization of return as a function of contemporaneous earnings level and change plus other value-relevant information (Feltham and Ohlson 1995; Ohlson 1995). But in an acknowledgement that assets are the source of earnings, Ohlson (1995) shows in his equation (7) a restatement of his model with valuation as a weighted average of book value, earnings and other information. Penman and Yehuda (2006) analyze a specification which uses beginning-of-period book value as a conditioning variable to explain annual returns, and in empirical tests they obtain significantly positive coefficients on annual earnings.

In summary, four decades of empirical and theoretical accounting research into the returnsearnings association provide guidance for the present investigation. In an informationally efficient market, January returns should be positively associated with first-quarter accounting earnings but this assumption has never been tested until now. I use two different empirical specifications of Ohlson's (1995) characterization of the returns-earnings association: Ohlson's (2001) specification expressing returns as a function of earnings level, earnings change and other information is the primary test, with Penman and Yehuda's (2006) specification included for 
robustness. The results show that the anomalous nature of the small firm/January effect extends to a disruption of the association between returns and earnings. 


\subsection{Empirical specifications of Ohlson's (1995) valuation model}

\subsection{Earnings-based approach: Ohlson (2001)}

A rigorous theoretical discussion of the link between returns and earnings is provided in Ohlson (1995) and Feltham and Ohlson (1995). Empirical implications of the model are described in fuller detail in Ohlson (2001) and the present investigation retains the notation used in that paper for expected earnings. Subscripts indicate the observability date and superscripts indicate the accounting period end date. ${ }^{5}$ Thus $\bar{x}_{t}^{t+1} \equiv E_{t}\left(\widetilde{x}_{t+1}\right)$ simplifies the expression of the expectation operator, $E_{t}($.$) and permits clear differentiation between the observability and$ accounting period end dates. Individual firm subscripts, $i$, are left out for expositional simplicity.

Beginning with the following assumptions:

I. The value of the firm is equal to the present value of future expected dividends (PVED).

$$
P_{t}=\sum_{\tau=1}^{\infty}(r+1)^{-\tau} \bar{d}_{t}^{t+\tau}
$$

II. Clean surplus accounting (CSR). That is, change in book value is equal to earnings less dividends.

$$
b_{t}=b_{t-1}+x_{t}-d_{t}
$$

Using (2) to substitute recursively for the dividend term in (1) yields the residual income valuation (RIV) model:

$$
P_{t}=b_{t}+\sum_{\tau=1}^{\infty}(r+1)^{-\tau} \bar{x}^{a, t+\tau}
$$

\footnotetext{
${ }^{5}$ Lack of a superscript means the accounting period end date is the same as the observability date. [See (Ohlson 2001), p. 113.]
} 
III. Expected future abnormal earnings at time $t$ are a linear function of current abnormal earnings and other value-relevant information. (Ohlson 1995 calls this assumption [A3].)

$$
\begin{aligned}
& \bar{x}_{t}^{a, t+1}=\omega x_{t}^{a}+v_{t}, 0 \leq \omega<1 \\
& v_{t}=\gamma v_{t-1}, 0 \leq \gamma<1 \\
& P_{t} \quad=\text { market value of equity at time } t \\
& r \quad=\text { the discount factor } \\
& d_{t} \quad=\text { net dividends at time } t \\
& b_{t} \quad=\text { book value at time } t \\
& x_{t} \quad=\text { earnings for the period }(t-1, t) \\
& x_{t}^{a}=\text { abnormal earnings (residual income) for the period }(t-1, t) \text {, where } \\
& x_{t}^{a} \equiv x_{t}-r b_{t-1} \\
& \bar{x}_{t}^{a, t+1}=\text { expectation at time } t \text { of abnormal future earnings for the period }(t, \\
& t+1) \\
& v_{t}=\text { a scalar variable representing other information relevant to } \\
& \text { forecasting earnings } \\
& \omega, \gamma=\text { parameters relating } x_{t}^{a} \text { and } v_{t-1} \text { to } x_{t}^{a, t+1} \text { and } v_{t} \text {, respectively; the } \\
& \text { parameter values are known by the market but not by researchers. }
\end{aligned}
$$


Combining PVED, CSR and [A3] yields an expression defining firm value as a function of book value, current abnormal earnings and other information not yet captured in earnings but relevant for forecasting future earnings:

$$
P_{t}=b_{t}+\alpha_{1} x_{t}^{a}+\alpha_{2} v_{t}
$$

where $\alpha_{1}=\frac{\omega}{(r+1-\omega)}$ and $\alpha_{2}=\frac{r+1}{(r+1-\omega)(r+1-\gamma)}$.

The form of (4) presents challenges to empirical researchers. Measuring abnormal earnings presumes knowledge of the true value of the discount rate. Approximations for the discount rate exist (for example, Collins and Kothari 1989 use beta risk and market risk premium). The exact definition of and measurement method for "other information," $v_{t}$, is less certain and one approach is to assume that $v_{t}$ is equal to zero. Ohlson (2001) warns that assuming $v_{t}$ equal to zero is analytically convenient but may be overly simplistic; however, studies using this approach (Easton et al. 1992; Easton and Harris 1991; Penman and Sougiannis 1998 are three examples) provide evidence that earnings variables resulting from accrual accounting explain returns.

Algebraic manipulation of equation (4), shown in Appendix A1, yields an expression portraying returns as a function of current earnings level, earnings change, and change in expectations for future earnings:

$$
\frac{P_{t}-P_{t-1}+d_{t}}{P_{t-1}}=(1-r \lambda) \frac{x_{t}}{P_{t-1}}+\left(\alpha_{1}-\alpha_{2} \omega\right) \frac{x_{t}-x_{t-1}}{P_{t-1}}+\alpha_{2} \frac{\bar{x}_{t}^{t+1}-\bar{x}_{t-1}^{t}}{P_{t-1}}+r \lambda \frac{d_{t}}{P_{t-1}}
$$

Of the four terms appearing on the right-hand side of (5), three are readily observable and measurable. Earnings and earnings changes can be easily obtained from a variety of publicly available sources. The problematic term $v_{t}$ in (4) is transformed through recursive substitution to 
the change in expectations for future earnings, which may be measured as the revision in analysts' forecasts for empirical purposes (Ohlson 2001). The fourth term, $r \lambda \frac{d_{t}}{P_{t-1}}$, may be thought of as bias or measurement error in the dependent variable and captured in the intercept term of a linear regression.

\subsection{Implementation issues}

\subsubsection{Beginning-of-period dates for price deflators}

Using a broad definition of "contemporaneous" earnings creates a third potential issue with regard to the price deflator when the beginning and end dates of the earnings periods do not match the beginning and end dates of the holding return of interest. ${ }^{6}$ Should $P_{t-1}$ deflating the earnings variables be the same as $P_{t-1}$ in the dependant variable return? Christie (1987) argues that using price as the deflator for independent variables in a returns regression "...follows solely from the definition of rate of return as the independent variable."7 Collins and Kothari (1989) follow this approach in their study of ERC determinants, deflating their earnings variables by price at the beginning of the return interval being tested even though the return periods do not always align with the earnings periods. The return intervals in Easton et al. (1992) correspond to earnings announcement dates rather than earnings intervals, and they also define their right-hand side price deflator as the price at the beginning of the return period.

A less mechanically rigid answer to the question of price deflator comes from the insight that an earnings-price ratio is informative because the beginning-of-period price in the denominator portrays the market's perception of expected future earnings (Beaver and Morse 1978). Ohlson

\footnotetext{
${ }^{6}$ For instance, when January returns of year $t$ are compared with fourth quarter earnings of year $t-1$, the beginning and ending dates of the return period are $12 / 31 / \mathrm{t}-1$ and $01 / 31 / \mathrm{t}$ but the dates of the earnings period are $10 / 31 / \mathrm{t}-1$ to $12 / 31 / \mathrm{t}-1$.

${ }^{7}$ Page 237.
} 
and Juettner-Nauroth (2005) capture this intuition more formally in their model relating the forward earnings-price ratio to future growth in earnings. This line of reasoning suggests that the appropriate price deflator for earnings variables is the price at the beginning of the earnings period of interest, regardless of whether it matches the beginning-of-period price for the return. In other words, price change is deflated by beginning-of-period price for the return interval of interest and earnings variables are deflated by beginning-of-period price for the earnings period of interest, and mismatches between the deflators are allowed. This is the approach used in Easton and Harris (1991), and the one followed in this paper.

\subsubsection{Availability of analysts' forecasts for small firms}

One complication related to utilizing the full model specification in (5) for the present study is that the population of particular interest is small firms due to the inverse relationship between firm size and the magnitude of January returns. Analyst following is negatively related to firm size (Bhushan 1989; Dempsey 1989), making it difficult to obtain sufficient analyst forecast data for this study. Therefore the choice is made to utilize a reduced form of the model which does not contain a term representing the change in analysts' forecasts. If the change in expectations for future earnings represented by the term $\alpha_{2} \frac{\bar{x}_{t}^{t+1}-\bar{x}_{t-1}^{t}}{P_{t-1}}$ is indeed an important explanatory variable then this reduced form of the model is subject to the correlated omitted variables problem: estimated coefficients will be biased and inferences will be suspect. However, as the focus of this investigation is small firms, and as analysts' forecasts for small firms are unlikely to be available to provide value relevant information for investors, the concession is judged to be reasonable. 


\subsubsection{General regression specification based on Ohlson (2001)}

Transforming Ohlson's (2001) notation and dropping the change in earnings forecast $\alpha_{2} \frac{\bar{x}_{t}^{t+1}-\bar{x}_{t-1}^{t}}{P_{t-1}}$ from (5), the general regression model in this paper is of the form used in Easton and Harris (1991).

$$
R_{t}=\theta_{0}+\theta_{1} \frac{x_{t}}{P_{x t-1}}+\theta_{2} \frac{x_{t}-x_{t-1}}{P_{x t-1}}+\mu_{t}
$$

where

$$
\begin{aligned}
& R_{t}=\frac{P_{t}-P_{t-1}+d_{t}}{P_{t-1}} \\
& x_{t}=\text { earnings per share for the period } t \\
& P_{t-1}=\text { price per share at beginning of the return period } \\
& P_{x t-1}=\text { price per share at beginning of the earnings period } \\
& \theta_{0}=r \lambda \frac{d_{t}}{P_{x t-1}}+\alpha_{2} \frac{\bar{x}_{t}^{t+1}-\bar{x}_{t-1}^{t}}{P_{x t-1}}, \text { the intercept } \\
& \theta_{1}=1-r \lambda \\
& \theta_{2}=\alpha_{1}-\omega \alpha_{2} \\
& \mu_{t}=\text { regression error }
\end{aligned}
$$

In the case of annual earnings, the earnings change term is obtained by subtracting annual earnings per share for year $t-1$ (represented as $E P S_{a t-1}$ ) from $E P S_{a t}$. In the case of quarterly earnings, earnings change is defined as $x_{q n, t}-x_{q n, t-1}$ in order to properly capture the strong seasonal component in quarterly earnings (Brown and Rozeff 1978; Easton and Zmijewski 1989; Foster 1977). 


\subsection{Book value as a conditioning variable: Penman and Yehuda (2006)}

Recalling that price may be expressed as a weighted average of earnings and book value along with other information (Ohlson 1995), Penman and Yehuda (2006) note that in an ideal world where earnings capture all value-relevant information and are measured perfectly, price is equal to book value. But, they argue, real world conservative accrual accounting is likely to result in earnings "mismeasurement" and a balance sheet "error" reflected as a difference between price and book value:

$$
P_{t}=b_{t}+\left(P_{t}-b_{t}\right)
$$

Differencing (7), applying CSR from (2) and deflating by price yields

$$
\frac{P_{t}-P_{t-1}+d_{t}}{P_{t-1}}=\frac{x_{t}}{P_{x t-1}}+\frac{b_{t-1}}{P_{x t-1}}+\left(\frac{P_{t}-b_{t}}{P_{t-1}}-1\right)
$$

Equation (8) expresses return as a function of earnings, beginning-of-period book value, and current premium to book value. (A more detailed discussion of the current premium to book value term is contained in Appendix A2.) Capturing this term in the intercept of the regression results in the following empirical specification:

$$
R_{t}=a_{0}+a_{1} \frac{x_{t}}{P_{x t-1}}+a_{2} \frac{b_{t-1}}{P_{x t-1}}+\varepsilon_{t}
$$

with all variables and subscripts as defined as described in the previous section.

Penman and Yehuda (2006) treat price-deflated beginning-of-period book value as an initializing variable in explaining the association between returns and earnings although they point out that its role in the regression is unclear. ${ }^{8}$ My adaptation of their specification ${ }^{9}$

\footnotetext{
${ }^{8}$ Penman and Yehuda present three possible functions for beginning-of-period book value. It may signify net assets that are the basis for future earnings and under a condition of conservative accounting with growth $\frac{b_{t-1}}{P_{x t-1}}$ is
} 
(hereafter referred to as PY2006) is used as a robustness check on the results obtained under the pure earnings approach. The empirical issues and descriptive subscript rules discussed in section 3.2 apply for this specification of the model as well, and careful attention to subscripts is necessary.

\subsection{Reverse regression}

Both Beaver et al. (1987) and Collins and Kothari (1989) use reverse regression, with earnings as the dependent and returns as the independent variables, in their studies of the association between price and earnings in order to alleviate the problem of earnings measurement error (Ryan 1986, 1988). Valuation models are rarely amenable to the simple switching technique of reverse regression because they generally recognize earnings as one of multiple explanatory variables. Consequently, the use of reverse regression is not widespread in recent accounting literature. However, Beaver et al. (1987) suggest that reverse regression offers an opportunity to analyze associations between earnings and components of returns and it is used here to probe the predictive value of the returns of individual months in the contemporaneous earnings period as another robustness check on the relationship between January returns and earnings.

positively correlated with $\frac{x_{t}}{P_{x t-1}}$. Or, it may proxy for risk and act as a control for expected returns (Fama and French 1992). Finally, $\frac{b_{t-1}}{P_{x t-1}}$ may act as a control for an inefficient market's inability to correctly price book value.

${ }^{9}$ The regression specification in equation of Penman and Yehuda,

$\frac{P_{i t}-P_{i t-1}}{P_{i t-1}}=a+b_{1} \frac{\text { Earnings }}{P_{i t-1}}+b_{2} \frac{d_{t}}{P_{t-1}}+b_{3} \frac{B V_{i t-1}}{P_{t-1}}+\varepsilon_{t}$, which appears as their equation 13 is slightly different from my specification because of a difference in investigative focus - one of their goals is to isolate the informational effects of dividends and accounting cash flows to price. See their discussion of accounting relations and regression specifications beginning on page 13 of the working paper. 
In the case of annual earnings I separate the contemporaneous annual holding return into the twelve separate monthly holding returns, and in the case of quarterly earnings the holding returns of that quarter's months are used. The general form of the reverse regression model is:

$$
\frac{x_{t}}{P_{x t-1}}=\phi_{0}+\sum_{\tau=1}^{n} \phi_{\tau} R_{m \tau}+\delta_{t}
$$

where

$$
\begin{aligned}
n= & \text { number of terms in the regression equation: } 12 \text { for annual earnings } \\
& \text { and } 3 \text { for each quarter }
\end{aligned}
$$

\subsection{Coefficient predictions}

In the primary analysis, the general specification in (6) defines the intercept, $\theta_{0}$, in part as a function of current dividends and expectations of future earnings. There is no clear theoretical prediction for the sign of this coefficient, nor for limitations on its magnitude, and no prediction is made for $\theta_{0}$.

For the coefficient on earnings levels, $\theta_{1}=1-r \lambda=1-r \frac{(r+1-\omega \gamma)}{(r+1-\omega)(r+1-\gamma)}$ as described in the previous section. By [A3] both $\omega$ and $\gamma$ must be greater than or equal to zero, and the maximum value of $\theta_{l}$ is one. Both $\omega$ and $\gamma$ must also be less than one, and the minimum value of $\theta_{l}$ may approach but not equal zero. Thus, $0<\theta_{l}<1$ : the regression coefficient on the earnings level independent variable is predicted to be significantly positive and less than one. 
For the coefficient on earnings change, $\theta_{2}=\alpha_{1}-\omega \alpha_{2}=\frac{-\omega \gamma}{(r+1-\omega)(r+1-\gamma)}$. As both $\omega$ and $\gamma$ are non-negative and less than one, $\theta_{2} \neq 0$ must be non-positive. This theoretical prediction contrasts with extant empirical findings (Collins and Kothari 1989; Collins et al. 1987; Easton and Harris 1991; Easton et al. 1992) of generally positive (although weaker) associations between returns and earnings changes. As there is no clear resolution to the inconsistency between theoretical prediction and empirical results, hypotheses are stated consistent with results in previous empirical literature of positive associations between returns and contemporaneous earnings changes.

In the PY2006 specification the coefficient on earnings, $a_{1}$, is predicted to be positive. No predictions are made for $a_{0}$, the intercept value; nor for $a_{2}$, the coefficient on the conditioning variable.

In the reverse regressions, all $\varphi_{\tau}$ coefficients are predicted to be positive for both the annual and quarterly analyses. No predictions are made for the intercept term in either case.

For the remainder of the paper the following subscripts are used to indicate the time periods related to the various earnings and returns variables in specific analyses:

$$
\begin{array}{ll}
a & =\text { annual } \\
q n & =\text { quarterly, where } \mathrm{n}=1,2,3,4 \\
m & =\text { month, where } \mathrm{m}=1,2, \ldots 12 \\
t & =\text { year } \\
m / d / t & =\text { date of } P_{x t}: \text { month/day/year }
\end{array}
$$

For example, $R_{m l t}$ refers to the January holding return in year $t . x_{a t-1}$ refers to annual earnings of year $t-1$, and $\mathrm{x}_{q 3 t}$ refers to third quarter earnings of year $t$. The month, day and year of the 
price deflator for the right side of the regression are specified in the subscript in order to prevent confusion between model specifications due to potential allowable mismatches in beginning-ofperiod dates between earnings and return intervals.

This analysis focuses on small firms because previous literature has already firmly established the January effect as a small firm phenomenon. The earnings response coefficient $\left(\theta_{1}\right)$ should become larger as firm size increases, consistent with the results of previous research (Collins and Kothari 1989; Collins et al. 1987; Easton and Zmijewski 1989). No prediction is made for the variation of $\theta_{2}$, the coefficient on earnings change, with firm size. Similarly, in the PY2006 model used for robustness testing, $a_{l}$ is predicted to be larger for large firms than for small firms. 


\subsection{Research design}

\section{1 "Contemporaneous" returns and earnings}

As a study of returns and contemporaneous earnings, this project ideally would be carried out by mapping January returns into earnings of the same period. Of course this is not possible because firms report earnings information on quarterly and annual bases, not monthly - no data item called "January earnings" exists. Matching January returns with contemporaneous earnings thus requires some flexibility in approach. To examine as broad a definition of “contemporaneous" as possible, each year's January returns are tested against all three earnings numbers (first quarter earnings of the same year, fourth quarter and annual earnings of the previous year).

The most realistic candidate for an earnings period corresponding to January returns in any year $(t)$ is first-quarter earnings of year $(t)$ because it includes the month in question. This specification fits well with the idea that returns lead earnings, although to the extent that earnings of February and March are also included in earnings of the first quarter there is a bias against finding an effect for January returns alone. Prior evidence of positive associations between returns and future earnings (Collins et al. 1987; Easton et al. 1992; Warfield and Wild 1992) indicates that this specification is not without precedent in the accounting literature even though it is not exactly consistent with a strict adherence to the Ohlson model.

\section{H1: January returns in year (t) are positively associated with earnings level and earnings change for $q 1$ of year ( $t)$.}

The specification of the regression model for $\mathrm{H} 1$ is

$$
R_{m 1, t}=\theta_{0}+\theta_{1} \frac{x_{q 1, t}}{P_{12 / 31 / t-1}}+\theta_{2} \frac{x_{q 1, t}-x_{q 1, t-1}}{P_{12 / 31 / t-1}}+\mu_{t} .
$$


Other reasonable candidates for "contemporaneous" earnings periods that might be expected have an association with January returns in year $(t)$ are the annual and fourth-quarter earnings of year $(t-1)$. In contrast to the concept of returns leading earnings, this condition implies that returns reflect mere information leakage - information in prior-period earnings that is incorporated into price after the end of the earnings period because fourth quarter and annual earnings for the preceding year may be announced during January, or information about those earnings may be leaking prior to the formal announcement. The possibility that future returns could reflect information released in an announcement of past earnings is supported by evidence in the earliest studies of returns-earnings associations (Ball and Brown 1968; Beaver 1968) and in the semi-strong tests of market efficiency prompted by their results (see Fama 1991 for a detailed discussion of research examining price reactions to earnings announcements); it also fueled the literature stream addressing post-earnings announcement drift. Given the unusual nature of January returns, contemplation of an association between returns and past earnings even if somewhat contrary to modern accounting literature's general acceptance of Ohlson's characterization - is not unreasonable. Formal statements of hypotheses are:

H2: January returns in year ( $t$ ) are positively associated with annual earnings of year (t-1).

H3: January returns in year ( $t$ ) are positively associated with earnings of $q 4$ in year (t-1). 
The regression equations for $\mathrm{H} 2$ and $\mathrm{H} 3$ are, respectively,

$$
\begin{aligned}
& R_{m 1, t}=\theta_{0}+\theta_{1} \frac{x_{a, t-1}}{P_{12 / 31 / t-2}}+\theta_{2} \frac{x_{a, t-1}-x_{a, t-2}}{P_{12 / 31 / t-2}}+\mu_{t} \\
& R_{m 1, t}=\theta_{0}+\theta_{1} \frac{x_{q 4, t-1}}{P_{09 / 30 / t-1}}+\theta_{2} \frac{x_{q 4, t-1}-x_{q 3, t-1}}{P_{09 / 30 / t-1}}+\mu_{t} .
\end{aligned}
$$

\subsection{Data sample}

The data sample consists of December fiscal year-end firms trading ordinary common shares on NYSE, AMEX or NASDAQ from 1972 through 2005. The December fiscal year-end requirement is imposed so as to align starting and ending calendar dates for all firm-quarters. Selection parameters are:

1. Monthly holding return, price and outstanding share data from CRSP.

2. Price $\geq \$ 1$, to avoid creating extreme values from very small price deflators.

3. EPS (basic) excluding extraordinary items from Compustat. (DATA58 in the Compustat Industrial Annual file; DATA19 in the Compustat Industrial Quarterly file.)

4. Report date of quarterly earnings (RDQE) must be available in Compustat for each quarter. The report date for fourth-quarter earnings is assumed to be also the report date for annual earnings.

5. To be included in any year, a firm must have all Compustat data items for annual and all four quarters, and twelve months of CRSP data.

6. To be included in the sample for year $t$, a firm must have CRSP data available in year $t-1$.

The final sample spans the years 1972 to 2005 and contains 59,707 firm-year observations. The number of firms in each year ranges from 663 firms (1972) to 3,000 (2000). Firms are sorted into size quintiles for each year, where the market value of equity at the end of year $t-1$ is used to assign size quintile for year $t$. The smallest firms are in quintile one and the largest firms 
are in quintile five. EPS and price deflators are adjusted for stock splits and dividends using the cumulative adjustment factors provided in Compustat and CRSP. Tables 1 and 2 show summary statistics for the sample. Table 3 and Figure 1 show that the firm size and month effects are clearly present in the sample. January returns for quintile one firms in Table 3 are higher than the annual average in every year of the sample period. In Figure 1, January returns exceed the returns of the other 11 months for firms in the lower half of the sample. The magnitude of January returns varies negatively with firm size.

Potential distorting effects of outliers on regression results are alleviated by deleting the observations in each regression sample for which the absolute value of the cumulatively adjusted earnings (earnings change) deflated by cumulatively adjusted beginning of earnings period price is greater then 1.5. ${ }^{10}$ The report date of quarterly earnings data item is used to eliminate observations for which a firm's earnings were not reported in a timely manner (meaning by the end of the following quarter), as this may be an indicator of firms in financial distress. ${ }^{11}$

To mitigate effects of cross-firm correlation, the regression analyses are carried out using a modified Fama-MacBeth (1973) approach (hereafter, FM). ${ }^{12}$ Annual cross-sectional regressions are run for each quintile of market value and the mean and standard errors of the time series annual regression coefficients are used as bases for drawing inferences. The advantages of the FM technique are that variation in the annual values of the coefficients captures cross-sectional correlation between firms in the same year, and heteroskedasticity does not affect the standard error of the coefficient mean.

\footnotetext{
${ }^{10}$ This follows the method used by Easton and Harris (1991).

${ }^{11}$ Evidence of reduced informativeness of earnings in distressed firms is provided by Burgstahler and Dichev (1997), Hayn (1995) and Joseph and Lipka (2006).

${ }_{12}$ Mean coefficients resulting from annual Fama-Macbeth regressions are hereafter referred to as "FM coefficients."
} 
However, the FM approach does not correct for same-firm correlation across time. Fama and French (2002) propose adjusting the standard error of the mean using a factor based on the estimated correlation of the annual FM regression coefficients in order to address the difficulty of serial correlation in the sample. Appendix A3 contains a description of this adjustment. However, Peterson (2006) argues that three problematic issues arise with their recommended adjustment. First, the estimated correlation of the annual FM coefficients is not the same as correlation in the individual firm observations that causes the bias in the standard error. Second, estimated correlations based on a small number of observations are imprecise. Fama and French (2002) admit this issue may present a problem for their 35-year regression sample. As the maximum number of regression years in my sample is 33 , there is no reason to believe that precision here will be improved. Third, when the correlation of annual coefficients is positive the Fama and French (2002) adjustment reduces the bias in the standard error but does not eliminate it. But if the correlation is negative then applying the Fama and French (2002) adjustment makes the bias in the standard error worse. Given these potential issues, the FM coefficients in the present study were examined to determine the magnitude and direction of serial correlation. Untabulated results for regression coefficients for all earnings types (quarterly and annual, earnings levels and changes) show that statistically significant serial correlation of the coefficients occurs only sporadically, may be either positive or negative, and is considerably less in magnitude than the 0.75 correlation estimate in Fama and French (2002). As there is no clear reason for, nor advantage to, systematically adjusting FM standard errors for serial correlation in the present analysis, no adjustment is made. 


\subsection{Establishing benchmarks}

Table 4 Panel A shows that with respect to contemporaneous annual returns and earnings, analyzed using the FM approach, this sample provides results that are consistent with the findings of Easton and Harris (1991). The regression equation used in this baseline analysis is

$$
R_{a, t}=\theta_{0}+\theta_{1} \frac{x_{a, t}}{P_{12 / 31 / t-1}}+\theta_{2} \frac{x_{a, t}-x_{a, t-1}}{P_{12 / 31 / t-1}}+\mu_{a, t}
$$

and the mean FM coefficient is significantly positive for both contemporaneous earnings levels and earnings changes. In Panel B, the sample is partitioned according to quintile of firm size. Mean intercepts and coefficients $\theta_{1}$ and $\theta_{2}$ from the FM regressions are positive and significant for both the lowest and highest quintiles. The intercept term represents average returns, and consistent with the firm size effect the intercept is significantly higher for quintile one firms than for firms in quintile five. In contrast to the results of early research into characteristics and determinants of ERCs (Collins and Kothari 1989; Collins et al. 1987; Easton and Zmijewski 1989), the magnitude of the earnings level coefficient $\theta_{l}$ in Panel B is higher for small firms than for large. Paired t-tests of annual coefficients indicate that the difference is not significant between the two size groups, although it is possible that this test lacks power due to the fact that there are only 33 regression years in each quintile. A non-parametric test approach may address this issue.

Panels A and $\mathrm{B}$ of Table 5 contain results for regressions of quarterly holding returns on contemporaneous quarterly earnings and earnings changes. Thirty-three annual cross-sectional regressions are performed combining the data for all four quarters in each firm-year. Again, the Panel A results are consistent with Easton and Harris (1991): mean coefficients on both earnings levels and changes are positive and significant. 
The general regression equation for this analysis is

$$
R_{q n, t}=\theta_{0}+\theta_{1} \frac{x_{q n, t}}{P_{x q n, t-1}}+\theta_{2} \frac{x_{q n, t}-x_{q n, t-1}}{P_{x q n, t-1}}+\mu_{q n, t},
$$

where $P_{x q n, t-1}$ is the appropriate beginning-of-earnings-period price deflator for each firm-quarter and $R_{q n, t}$ is the firm's 3-month holding return during quarter $n$.

As in Warfield and Wild (1992), the adjusted $\mathrm{R}^{2}$ values shown in Panel A of Table 5 indicate that the explanatory power of quarterly earnings variables is smaller than those of the annual earnings variables shown in Panel A of Table 4. Consistent with previous evidence on the small firm effect, the mean return of small firms in Table 5 Panel B is significantly higher than that of large firms. As predicted, the mean value of $\theta_{1}$ is positive and significant and the magnitude of $\theta_{l}$ is larger for large firms than for small firms but the paired t-test of the annual values does not indicate that the difference is significant. It is possible that the firm size effect documented by Collins et al. (1987), Collins and Kohari (1989) and Easton and Zjimesksi (1989) may be obscured due to the relatively short monthly (quarterly) periods over which returns (earnings) are being measured in this analysis. As in the corresponding analysis in Table 4, a non-parametric test approach may offer more insight for comparing coefficients of the different firm size groups. Because small firms are the population of interest with respect to the January effect the rest of the paper focuses on analysis results for firms in quintile one, that is, the smallest $20 \%$ of firms in the sample.

The January effect literature rests on empirical evidence that returns of small firms in January are generally significantly higher than in other months, raising the possibility that the explanatory power of the returns-earnings model for the first quarter could differ from other quarters. Unfortunately there is little previous research involving contemporaneous monthly returns-quarterly earnings associations, particularly with regard to considering any differences 
between quarters. As the focus of this investigation is January returns and first-quarter earnings, I first examine the associations between returns and earnings in the second, third and fourth quarters, testing both the first-month returns and the quarterly (three-month) returns for these three quarters in order to establish a benchmark for comparison of January and first quarter results. This approach provides additional support for inferences regarding the behavior of January returns with respect to contemporaneous earnings. The specific regression equations for the second, third and fourth quarters are:

First-month returns - quarterly earnings

$$
\begin{aligned}
& R_{m 4, t}=\theta_{0}+\theta_{1} \frac{x_{q 2, t}}{P_{03 / 31 / t}}+\theta_{2} \frac{x_{q 2, t}-x_{q 2, t-1}}{P_{03 / 31 / t}}+\mu_{t} \\
& R_{m 7, t}=\theta_{0}+\theta_{1} \frac{x_{q 3, t}}{P_{06 / 30 / t}}+\theta_{2} \frac{x_{q 3, t}-x_{q 3, t-1}}{P_{06 / 30 / t}}+\mu_{t} \\
& R_{m 10, t}=\theta_{0}+\theta_{1} \frac{x_{q 10, t}}{P_{09 / 30 / t}}+\theta_{2} \frac{x_{q 10, t}-x_{q 10, t-1}}{P_{09 / 30 / t}}+\mu_{t}
\end{aligned}
$$

Quarterly returns - quarterly earnings

$$
\begin{aligned}
& R_{q 2, t}=\theta_{0}+\theta_{1} \frac{x_{q 2, t}}{P_{03 / 31 / t}}+\theta_{2} \frac{x_{q 2, t}-x_{q 2, t-1}}{P_{03 / 31 / t}}+\mu_{q 2, t} \\
& R_{q 3, t}=\theta_{0}+\theta_{1} \frac{x_{q 3, t}}{P_{06 / 30 / t}}+\theta_{2} \frac{x_{q 3, t}-x_{q 3, t-1}}{P_{06 / 30 / t}}+\mu_{q 3, t} \\
& R_{q 4, t}=\theta_{0}+\theta_{1} \frac{x_{q 4, t}}{P_{09 / 30 / t}}+\theta_{2} \frac{x_{q 4, t}-x_{q 4, t-1}}{P_{09 / 30 / t}}+\mu_{q 4, t}
\end{aligned}
$$

To the extent that the independent variables in the first three regressions consist of earnings generated during all three months in each quarter while the dependent variable is limited to the 
first month's return, there is some disconnect in the contemporaneousness of the relationship between the two which should bias against finding significant results in any of these quarters.

Results are shown in Table 6, Panels A and B. The earnings level coefficient $\theta_{1}$ is significantly positive in all three quarters for first-month as well as quarterly holding returns. The earnings change coefficient is positive in all three quarters, but not significantly different from zero in the fourth quarter regardless of whether the return period is one month or the entire quarter. The mean $\mathrm{R}^{2}$ values for contemporaneous quarterly returns and earnings regressions for the three quarters separately in Table 6 Panel B are all at least twice as high as the mean $\mathrm{R}^{2}$ of 0.015 when all four quarters are combined (Table 5, Panel A).

Although the earnings change coefficient values for the fourth quarter are not significant for either first-month or entire quarter returns, the results in Table 6 establish a benchmark of overall positive associations between first-month returns and quarterly earnings for quarters two, three and four, and the results in these three quarters may still reasonably be used as a basis of comparison for analysis of first quarter return and earnings variables. The benchmark evidence here is consistent with the premise that first-month returns lead earnings of the contemporaneous quarter. Even with a bias against finding a result because of the imperfect match in timing between first-month returns and earnings, there is evidence of predictive value in the first month's returns for quarters two, three and four. 


\subsection{Analysis and results}

\subsection{January returns and first quarter earnings}

Now that a benchmark of positive association between first-month returns and earnings is established, the focus of the analysis shifts to January and the first quarter. Table 7 Panel A shows the regression coefficients for January returns-earnings regressions compared with those of April, July and October returns-earnings regressions. The results of the January-q1 regression are strikingly different from the other three quarters: the earnings level coefficient $\theta_{1}$ is actually negative. Given the results of previous literature and supported by the benchmark testing just completed, the hypothesis statement tests $\mathrm{H} 1_{0}: \theta_{1} \leq 0, \mathrm{H}_{\mathrm{a}}: \theta_{1}>0$. As the sign on $\theta_{1}$ is directionally opposite that which is expected, I conduct a separate one-tail test in the other direction and find that $\theta_{1}<0$ with a p-value of 0.029 . In other words, not only is the coefficient on earnings level not positive, it is almost certainly negative. In contrast, the earnings change coefficient $\theta_{2}$ for January returns is positive and its magnitude is approximately three times higher in quarter one than in any other quarter.

Given the benchmark evidence in Table 6, Panel B that fully contemporaneous quarterly returns and earnings are positively associated it is reasonable to speculate that returns in February and March may somehow compensate for unusual January returns, resulting in a fully contemporaneous (over all three months) returns-earnings association for the first quarter that behaves as predicted. Results for the quarterly returns-earnings regressions for all four quarters are shown in Table 7, Panel B. Expanding the return holding period to all three months of the quarter yields mixed results with regard to the first quarter: $\theta_{1}$ is positive but not significantly different from zero. $\theta_{2}$ is still significantly positive and approximately three times larger in magnitude for the first quarter than in the other three quarters. 
Overall, the evidence in Table 7 does not support H1, the hypothesis that January returns and first-quarter earnings are positively associated. In fact, the sign of the earnings level association with January returns is directionally opposite from that predicted and seems to indicate that the better are January returns, the worse are first quarter earnings. Also, the association with earnings change is much stronger than for earnings level in the first quarter and much larger and stronger than in any other quarter. Assuming an efficient market with rational investors, it is difficult to interpret the meaning of these results or to understand why the earnings level coefficient is negative only for January returns in the first quarter.

In standard regression analysis, Chow tests could be used to evaluate whether differences in corresponding coefficients from the four different quarters are statistically significant, but because the coefficients in this paper are generated using a modified FM approach (they are means of coefficients resulting from multiple annual regressions) the Chow test is not appropriate. Instead, paired t-tests with a Bonferroni adjustment are used to evaluate differences in means for each coefficient across the four quarters. Results appear in Table 8, Panels A and B. Using a Bonferroni-adjusted $t$-statistic of $2.85^{13}$, the values of the first quarter intercept and earnings change coefficients are significantly higher than nearly all corresponding coefficient values in quarters two, three and four. The only exception is the difference between the quarter one and quarter three earnings change coefficient $\theta_{2}$ in Panel A, where the $t$-statistic of 2.76 just barely misses the hurdle of 2.85 . The negative value on the earnings level coefficient in quarter one is significantly lower than the earnings level coefficients in all other quarters. In contrast to

\footnotetext{
${ }^{13}$ For each coefficient having $g$ pairwise comparisons of interest the Bonferroni $t$-statistic for the family of tests with $\alpha=0.05$ is $t_{B o n}=t\left(1-\frac{\alpha}{g} ; n-p\right)$. Here, there are six pairings for each coefficient (quarter one with quarters two, three and four; quarter two with quarters three and four; quarter three with quarter four), resulting in a Bonferroni-adjusted $t$-statistic of 2.85 .
} 
differences from first quarter coefficients, none of the differences in coefficient values between quarters two, three or four have $t$-statistics that are even close to statistical significance, indicating that average returns and the predictive characteristics of those returns with respect to earnings is essentially the same across these three quarters.

Table 9 shows results of regressions in which the holding returns of only the last two months of each quarter (February and March, May and June, etc.) are regressed on that quarter's earnings levels and changes. Association of two months' holding returns with both earnings levels and changes is positive in all four quarters, and significantly so for quarters one through three. This provides additional support for the idea that it is the unusual nature of January returns in particular driving the results found in Table 7. Although February and March holding returns are positively associated with first quarter earnings, returns in these two months do not appear to compensate for the distortion of January returns, evidenced by the result in Table 7 Panel B that first quarter holding returns are not significantly greater than zero even with these two "well-behaved" months added to the holding period.

In summary, the association between returns and earnings is substantially disrupted for the first quarter where January returns are considered. The coefficient on earnings level is even significantly negative. The negative sign on this coefficient is mitigated when the returns period is lengthened to encompass the entire three months of the quarter, but the predicted positive association is not restored.

\subsection{Tests of $\mathrm{H} 2$ and $\mathrm{H3}$}

Panel A of Table 10 shows coefficient results for equation (12), in which January returns in year $(t)$ are regressed on annual earnings variables for year $(t-1)$. Panel B contains coefficient results for equation (13), using January returns in year $(t)$ and fourth-quarter earnings variables 
for year $(t-1)$. Results for both sets of earnings variables are similar to the results of regressing January returns on same-year first quarter earnings which appear in Panel A of Table 7: the intercepts and earnings change coefficients are positive and highly significant, but the earnings level coefficients are of the opposite sign predicted, and significantly so. As stated in the discussion of Table 7, the meaning of the negative sign and magnitude of the earnings level coefficient is difficult to interpret. Table 10 Panel $\mathrm{C}$ shows the results of regressing April (July/October) returns on past quarterly earnings, providing a comparison to the results for January returns and fourth-quarter earnings in Panel B. Consistent with findings in extensive previous research both $\theta_{1}$ and $\theta_{2}$ are positive and significant for the April (July/October) returns on first (second/third) quarter earnings regressions. Once again, there is evidence that the nature of the association between January returns and earnings deviates significantly from predictions based on extant theory and empirical literature.

\subsection{Alternate sample partitions}

Given the drastic difference in results between the first quarter and the other three, a closer look at characteristics of first-quarter returns and earnings is warranted. For instance, extant empirical research consistently documents higher returns for small firms in the month of January than in the other 11 months of the year. But is the January effect truly an annual event? Figure 2, a simple plot of the time-series of mean January returns for quintile one firms overlaid with indicators showing the years for which the mean January return is higher than the mean for all other months, demonstrates quite clearly that the answer is no. In fact, in the 34 years from 1972 to 2005 (inclusive), a true "January effect" year occurs in only 16 , or $47.1 \%$, of those years. This result suggests that the January effect may not be as pervasive as implied by widespread findings in empirical literature of high returns for small firms in January. Although this partition is 
helpful in that it suggests there may be some limit to the January anomaly, it reduces the number of years in each sub-sample for use in FM regression and results in low power.

Another option is to separate firms which are truly "January effect" (hereafter, "JE") firms in any given year from those that are "non-January effect" firms (hereafter, "NJE"). Following the logic outlined for the January effect years partitioning, I define JE firms as firms whose January return is higher than the mean of returns during the other 11 months of the year, and partition the firms for each year in the sample. ${ }^{14}$ A firm may be designated as a JE firm in one year, but not in the next - it depends on the firm's monthly returns in each year. Summary statistics for this partitioning of the sample are shown in Table 11. Panel A shows that $61.8 \%$ of quintile 1 firms are categorized as JE firms, decreasing to $47.2 \%$ of firms in quintile 5 . Share price summary data is shown in Panel B, where the smallest and largest JE (NJE) firms generally have lower (higher) share prices. Panel C shows comparative \$EPS summary statistics for the two firm types. Quintile 1 firms only are shown for conciseness; the differences between JE firms and NJE firms become smaller as firm size increases and essentially disappear in Quintile 5. Although median \$EPS values for Quintile 1 firms are very close to equal, the distributions of JE firms are skewed heavily downward and JE means are much lower than the means of NJE firms for annual \$EPS and all quarters except the second.

To ensure that this partitioning of the sample does not merely reflect the firm size component of the January anomaly I conduct a detailed examination of firm size and type for each quintile, dividing the quintiles in the full sample into 100 annual sub-sets ("percentiles") of firm size and counting the number of JE and NJE firms assigned to each percentile. If the partition of firms

\footnotetext{
${ }^{14}$ Another possible definition of JE firms is quintile one firms for which the January holding return is the highest of the monthly returns in any given year. Under this definition only $17.8 \%$ of the quintile one firm-year observations are classified as JE firms. However, the number of firms in the JE subset in a particular year may be low under such a strict definition, making regression analysis using FM methodology difficult. Therefore, this definition is not used in the present analysis.
} 
into JE versus NJE is simply a reflection of the firm size component of the joint small firm/January effect, then the JE firms will be clustered among the lowest size percentiles. Figure 3 shows that this is not the case: JE firms are distributed fairly evenly across quintile 1 . The same is true for quintiles 2 through 5 although the analyses are not included here in the interest of brevity.

Table 12 shows results of regressing January returns on first-quarter earnings for the two populations. The mean intercepts are significant but of opposite signs: $\theta_{0}$ for JE firms is highly positive at 0.173 , while $\theta_{0}$ for NJEs is -0.053 , a difference in mean returns of $22.6 \%$. The earnings level coefficient $\theta_{1}$ is significantly negative for JE firms and significantly positive for NJEs. The earnings change coefficient $\theta_{2}$ is positive and highly significant for JE firms but not significantly different from zero for NJE firms.

Partitioning the sample between JE firms and NJE firms highlights the curious and unexpected negative association between January returns and first-quarter earnings for firms that experience the January effect. Although the average return of NJE firms is negative, these firms do exhibit a positive association between January returns and contemporaneous earnings as predicted based on extant theory, previous empirical research and the baselines established earlier in this study. 


\subsection{Robustness checks}

\subsection{PY2006 analysis}

In the first robustness check of the evidence obtained using the pure earnings specification, I introduce beginning-of-period book value to the examination of the returns-earnings association, using the PY2006 approach based on equation (9).

Continuing the use of the modified FM methodology, I run the regression equation annually in the cross-section and report the mean of the annual coefficients. I also provide results for quarters two, three and four in order to provide a benchmark against which to compare results for the January returns-first quarter earnings association. The regression equations for the four quarters are, respectively:

$$
\begin{aligned}
& R_{m 1, t}=a_{0}+a_{1} \frac{x_{q 1 t}}{P_{12 / 31 / t-1}}+a_{2} \frac{b_{q 4}}{P_{12 / 31 / t-1}}+\varepsilon_{t} \\
& R_{m 4, t}=a_{0}+a_{1} \frac{x_{q 2 t}}{P_{03 / 31 / t}}+a_{2} \frac{b_{q 1}}{P_{03 / 31 / t}}+\varepsilon_{t} \\
& R_{m 7, t}=a_{0}+a_{1} \frac{x_{q 3 t}}{P_{06 / 30 / t}}+a_{2} \frac{b_{q 2}}{P_{06 / 30 / t}}+\varepsilon_{t} \\
& R_{m 10, t}=a_{0}+a_{1} \frac{x_{q 4 t}}{P_{09 / 30 / t}}+a_{2} \frac{b_{q 3}}{P_{09 / 30 / t}}+\varepsilon_{t}
\end{aligned}
$$

where $b_{q n}=$ ending book value for quarter $n$, where $n=1,2,3,4$ and represents the quarter previous to the earnings quarter; all other variables are as defined previously.

Penman and Yehuda (2006) suggest that if beginning-of-period book value initializes for earnings-producing assets then $\frac{b_{t-1}}{P_{x, t-1}}$ is positively correlated with $\frac{x_{t}}{P_{x, t-1}}$. They provide evidence of such positive correlation between beginning-of-period book value and annual earnings for 
their sample in their Table 1. Mean Pearson correlations for the variables in this study are shown in Table 13, Panel A. Consistent with the results of Penman and Yehuda (2006) mean correlations between price-deflated beginning-of-period book value and earnings are positive in the first three quarters; the negative value in the fourth quarter is not significantly different from zero. This result implies that book value may initialize for earnings-producing assets at the quarterly level as well as at the annual level. For the second, third and fourth quarters the mean correlations between first-month returns and book values, and also between first-month returns and earnings, are positive, evidence that is also consistent with Penman and Yehuda's (2006) results for annual variables. In contrast, the mean correlation between returns and beginning-ofperiod book value in the first quarter is significantly negative, and the mean correlation between returns and earnings is insignificantly different from zero. Taken together, these results suggest that the accounting relationships between earnings and book values survive at the quarterly level but the associations between returns and the accounting variables is disrupted in the first quarter.

Table 13 Panel B shows coefficient results for the PY2006 regression analyses. In quarters two, three and four the intercept $a_{0}$ is not significantly different from zero, and quarterly earnings are positively and significantly associated with first-month returns. The coefficient on book value $a_{2}$ is positive but significantly different from zero only in the third quarter. These results are compatible with the PY2006 findings for their intercepts and annual earnings terms, although their reported coefficients on annual beginning-of-period book value are significant. ${ }^{15}$ The results for first-month returns in quarters two, three and four provide a benchmark that is consistent with PY2006, but the results for January returns and first quarter earnings are similar to the pure earnings approach in that they differ drastically from the benchmark. The January returns-first quarter earnings regression intercept $a_{0}$ is highly positive and significant with a

\footnotetext{
${ }^{15}$ See Table 2 (Penman and Yehuda 2006).
} 
value of 0.099 ; the coefficient on earnings, $a_{1}$, is negative but not significantly different from zero. The $a_{2}$ coefficient is also negative although it is not significantly different from zero, which is generally consistent with the benchmark.

Table 13 Panel C shows results for the first-quarter PY2006 regression when the sample is partitioned between JE and NJE firms. Unlike the results in Table 12 - but similar to the firstquarter results in Panel B of Table 13 - the earnings coefficient in Panel C is insignificant for both subsets. Although the results in PY2006 and the benchmark analysis in this paper would be consistent with a positive sign on $a_{2}$, the coefficient on beginning-of-period book value in the partitioned sample is significantly negative for JE firms and significantly positive for NJE firms. In the presence of the balance sheet component (beginning-of-period book value) utilized in this specification there is apparently no statistical link between returns and earnings during the first quarter, and the association between returns and book value seems to suggest that the lower is book value for JE firms the higher are returns. It is difficult to suggest a reasonable interpretation of these results. 


\subsection{Reverse regressions}

The reverse regression technique laid out in section 3.4 provides an additional robustness check of the association between January returns and earnings by evaluating the contribution of individual months to the entire period in question. The individual reverse regression equations for annual and quarterly earnings periods are, respectively:

$$
\begin{aligned}
& \frac{x_{a, t}}{P_{12 / 31 / t-1}}=\phi_{0}+\sum_{\tau=1}^{12} \phi_{\tau} R_{m \tau}+\delta_{t} \\
& \frac{x_{q 1, t}}{P_{12 / 31 / t-1}}=\phi_{0}+\phi_{1} R_{m 1, t}+\phi_{2} R_{m 2, t}+\phi_{3} R_{m 3, t}+\delta_{t} \\
& \frac{x_{q 2, t}}{P_{03 / 31 / t}}=\phi_{0}+\phi_{4} R_{m 4, t}+\phi_{5} R_{m 5, t}+\phi_{6} R_{m 6, t}+\delta_{t} \\
& \frac{x_{q 3, t}}{P_{06 / 30 / t}}=\phi_{0}+\phi_{7} R_{m 7, t}+\phi_{8} R_{m 8, t}+\phi_{9} R_{m 9, t}+\delta_{t} \\
& \frac{x_{q 4, t}}{P_{09 / 30 / t}}=\phi_{0}+\phi_{10} R_{m 10, t}+\phi_{11} R_{m 11, t}+\phi_{12} R_{m 12, t}+\delta_{t}
\end{aligned}
$$

Results are shown in Table 14. In two-tail tests of the individual months' returns and earnings at both the annual and quarterly levels, January returns are once again unique in their lack of significant association with earnings. This provides additional confidence that the apparent disruption, specific to January, in the returns-earnings association is not a spurious result of the investigative methods used in this paper. 


\subsection{Summary and conclusions}

Previous theoretical and empirical accounting research supports the theory that returns reflect information in contemporaneous earnings. Evidence presented in this paper demonstrates that, as expected, a positive association between returns and earnings is present for annual returns and earnings and also, overall, for quarterly returns and earnings. Closer analysis of the returnsearnings association at the quarterly level shows that in the first quarter only, the expected predictive ability of returns for earnings does not hold and in fact the association may actually be negative. In addition, there is evidence that this curious association between January returns and earnings in the first quarter is similar to the association of January returns with past earnings. Further, I demonstrate that the small firm/January effect anomaly is not universally experienced by small firms, either temporally or in the cross-section. In striking contrast to the significantly negative first quarter association between returns and earnings found for small firms that do experience the January effect, small firms whose January returns are not higher than those in the rest of the year exhibit a positive returns-earnings association in the first quarter as well as in quarters two, three and four.

Taken together, the results of this investigation indicate a serious disruption - possibly a complete disconnect - in the returns-earnings relationship of the first quarter which appears to hinge upon the anomalous nature of "January effect" returns. Interestingly, the correlations between accounting variables - earnings and book value - survive in the first quarter despite the interruption of the relationship between earnings and price.

At present it is difficult to propose an interpretation of these results that is either meaningful or intuitively pleasing. If abnormally high January returns are not linked to contemporaneous 
earnings, then one struggles to comprehend their economic relevance, particularly since January is the only month in which this phenomenon is consistently observed.

Much work remains to be done to attain a better understanding of the nature of the returnsearnings relationship for small firms in the first quarter, particularly for firms that experience the January effect. For instance, the lack of an empirical specification in this investigation for the change in analysts' forecasts may have more serious implications for the first quarter than for other quarters. It is also possible that characteristics of earnings and/or earnings changes for firms that experience a January effect may be different from those of firms that do not experience it. Additional analysis of these possibilities should yield additional insights and provide a better understanding of small firm/January effect. 


\section{Tables and Figures}

\section{Tables}

Table 1 Median firm size measured as market value of equity (\$MM) and number of firms by quintile and year in the full sample.

\begin{tabular}{|c|c|c|c|c|c|c|c|}
\hline \multicolumn{8}{|c|}{ Quintile of market value } \\
\hline Year & 1 & 2 & 3 & 4 & 5 & $\begin{array}{c}\text { Pooled } \\
\text { Sample }\end{array}$ & $\begin{array}{c}\text { Number } \\
\text { of firms }\end{array}$ \\
\hline 1972 & 8.9 & 29.1 & 91.4 & 258.4 & $1,072.4$ & 91.0 & 663 \\
\hline 1973 & 8.6 & 28.8 & 76.5 & 234.4 & 994.6 & 76.5 & 795 \\
\hline 1974 & 5.5 & 19.6 & 59.6 & 192.4 & 751.2 & 59.4 & 1,036 \\
\hline 1975 & 3.7 & 14.8 & 41.0 & 127.4 & 583.9 & 40.9 & 1,068 \\
\hline 1976 & 7.6 & 28.3 & 72.9 & 209.1 & 796.6 & 72.6 & 1,024 \\
\hline 1977 & 7.9 & 31.8 & 89.7 & 250.0 & 972.2 & 89.7 & 1,128 \\
\hline 1978 & 8.3 & 35.2 & 97.5 & 264.5 & 927.5 & 97.2 & 1,097 \\
\hline 1979 & 9.5 & 37.5 & 103.8 & 289.4 & 956.0 & 103.7 & 1,073 \\
\hline 1980 & 12.1 & 52.1 & 131.4 & 358.2 & $1,148.7$ & 131.3 & 1,061 \\
\hline 1981 & 13.1 & 63.1 & 165.0 & 434.2 & $1,566.9$ & 165.0 & 1,048 \\
\hline 1982 & 14.0 & 62.6 & 174.7 & 436.4 & $1,453.2$ & 174.7 & 1,056 \\
\hline 1983 & 13.9 & 50.3 & 139.5 & 391.4 & $1,543.3$ & 139.5 & 1,270 \\
\hline 1984 & 18.3 & 58.9 & 158.1 & 442.3 & $1,655.0$ & 157.6 & 1,364 \\
\hline 1985 & 15.2 & 46.5 & 139.9 & 400.8 & $1,740.0$ & 139.7 & 1,373 \\
\hline 1986 & 17.8 & 58.5 & 167.5 & 502.3 & $2,194.8$ & 167.1 & 1,354 \\
\hline 1987 & 16.4 & 55.6 & 156.3 & 522.1 & $2,581.6$ & 156.2 & 1,418 \\
\hline 1988 & 13.6 & 44.5 & 135.1 & 464.6 & $2,267.1$ & 135.1 & 1,440 \\
\hline 1989 & 16.2 & 56.0 & 158.4 & 551.4 & $2,548.7$ & 158.3 & 1,452 \\
\hline 1990 & 19.0 & 72.3 & 206.0 & 732.1 & $3,243.6$ & 205.5 & 1,424 \\
\hline 1991 & 13.6 & 50.8 & 155.4 & 515.8 & $2,490.0$ & 155.4 & 1,520 \\
\hline 1992 & 17.8 & 66.9 & 178.2 & 626.0 & $2,937.1$ & 177.7 & 1,638 \\
\hline 1993 & 17.4 & 64.3 & 183.8 & 571.2 & $3,180.0$ & 182.8 & 1,853 \\
\hline 1994 & 20.1 & 64.3 & 160.8 & 487.5 & $2,845.3$ & 160.7 & 2,269 \\
\hline 1995 & 16.8 & 52.6 & 133.4 & 411.4 & $2,265.4$ & 133.4 & 2,436 \\
\hline 1996 & 21.4 & 70.2 & 172.3 & 510.2 & $2,988.4$ & 172.3 & 2,648 \\
\hline 1997 & 23.3 & 74.7 & 189.1 & 544.9 & $3,160.2$ & 188.7 & 2,844 \\
\hline 1998 & 29.4 & 95.8 & 229.9 & 648.7 & $3,676.4$ & 229.6 & 2,876 \\
\hline 1999 & 22.7 & 74.2 & 209.5 & 611.9 & $4,125.3$ & 209.5 & 2,848 \\
\hline 2000 & 21.9 & 76.2 & 235.4 & 753.4 & $4,190.4$ & 235.4 & 3,000 \\
\hline 2001 & 20.7 & 74.9 & 220.7 & 766.3 & $4,668.0$ & 220.7 & 2,845 \\
\hline 2002 & 28.1 & 96.4 & 294.1 & 873.9 & $4,705.6$ & 294.0 & 2,684 \\
\hline 2003 & 26.5 & 87.4 & 236.0 & 688.4 & $3,799.9$ & 236.0 & 2,675 \\
\hline 2004 & 38.7 & 136.7 & 362.0 & 941.5 & $4,809.0$ & 360.8 & 2,724 \\
\hline 2005 & 50.2 & 160.9 & 416.3 & $1,123.0$ & $5,619.1$ & 416.2 & 2,703 \\
\hline MVE & 17.7 & 65.7 & 179.1 & 549.5 & $2,722.7$ & & \\
\hline -years & 11,954 & 11,945 & 11,936 & 11,946 & 11,926 & & 59,707 \\
\hline
\end{tabular}


Table 2 Full sample summary statistics: Mean, standard deviation, and quartile values.

Panel A SEPS scaled by beginning-of-year price, cumulatively adjusted for stock splits and dividends.

\begin{tabular}{|c|c|c|c|c|c|}
\hline \multirow{2}{*}{\multicolumn{6}{|c|}{ Annual \$EPS }} \\
\hline & & & & & \\
\hline Std. dev. & 387.688 & 2.076 & 0.918 & 0.282 & 0.180 \\
\hline Upper quartile & 0.132 & 0.118 & 0.110 & 0.108 & 0.100 \\
\hline Median & 0.062 & 0.066 & 0.064 & 0.067 & 0.070 \\
\hline Lower quartile & -0.032 & 0.002 & 0.017 & 0.033 & 0.040 \\
\hline Quarter 1 \$EPS & -0.121 & 0.008 & 0.007 & 0.018 & 0.020 \\
\hline Mean & 6.175 & 0.243 & 0.602 & 0.056 & 0.040 \\
\hline Std. dev. & 0.028 & 0.026 & 0.026 & 0.026 & 0.030 \\
\hline Upper quartile & 0.013 & 0.014 & 0.014 & 0.015 & 0.020 \\
\hline Median & -0.008 & 0.001 & 0.004 & 0.007 & 0.010 \\
\hline Lower quartile & -0.121 & 0.008 & 0.007 & 0.018 & 0.020 \\
\hline \multicolumn{6}{|l|}{ Quarter 2 \$EPS } \\
\hline Mean & 0.074 & 0.012 & 0.015 & 0.018 & 0.020 \\
\hline Std. dev. & 7.359 & 0.279 & 0.083 & 0.130 & 0.050 \\
\hline Upper quartile & 0.037 & 0.031 & 0.029 & 0.028 & 0.030 \\
\hline Median & 0.018 & 0.017 & 0.016 & 0.017 & 0.020 \\
\hline Lower quartile & 0.000 & 0.003 & 0.005 & 0.009 & 0.010 \\
\hline \multicolumn{6}{|l|}{ Quarter 3 \$EPS } \\
\hline Mean & 0.095 & 0.021 & 0.015 & 0.019 & 0.020 \\
\hline Std. dev. & 5.003 & 1.282 & 0.082 & 0.072 & 0.080 \\
\hline Upper quartile & 0.037 & 0.032 & 0.030 & 0.029 & 0.030 \\
\hline Median & 0.017 & 0.017 & 0.017 & 0.017 & 0.020 \\
\hline Lower quartile & -0.002 & 0.002 & 0.004 & 0.008 & 0.010 \\
\hline \multicolumn{6}{|l|}{ Quarter 4 \$EPS } \\
\hline Mean & -4.165 & -0.011 & 0.007 & 0.014 & 0.020 \\
\hline Std. dev. & 394.712 & 1.124 & 0.292 & 0.097 & 0.080 \\
\hline Upper quartile & 0.040 & 0.033 & 0.031 & 0.029 & 0.030 \\
\hline Median & 0.016 & 0.017 & 0.017 & 0.017 & 0.020 \\
\hline Lower quartile & -0.017 & -0.004 & 0.002 & 0.007 & 0.010 \\
\hline
\end{tabular}

Panel B Beginning-of-year share price (\$), cumulatively adjusted for stock splits and dividends.

Mean

Std. dev.

Upper quartile

Median

Lower quartile
7.626

71.901

7.426

4.150

2.438

Quintile of market value

\section{2}

12.961

101.873

12.750

8.000

4.688

\section{3}

17.340

201.637

18.000

11.875

7.028
4

33.169

672.973

24.780

16.500

9.563
5

83.170

1940.540

33.710

21.560

12.020 
Table 2, continued

Panel C Monthly returns.

Mean

0.022

0.0227

2

0.0150

3

0.0828

0.1537

0.0761

0.0000

Median

$-0.0667$

0.0000

$-0.0625$

4

0.0115

5

$\begin{array}{lll}0.0132 & 0.0115 & 0.0102\end{array}$

$\begin{array}{lll}0.1471 & 0.1301 & 0.1037\end{array}$

$\begin{array}{lll}0.0758 & 0.0701 & 0.0607\end{array}$

Lower quartile

0.0061

0.0084

0.0094

$-0.0588$

$-0.0511$

$-0.0407$ 
Table 3 Firm size effect: mean January return in each quintile.

Quintile of market value

\begin{tabular}{|c|c|c|c|c|c|c|}
\hline Year & 1 & 2 & 3 & 4 & 5 & $\begin{array}{c}\text { Annual } \\
\text { mean }\end{array}$ \\
\hline 1972 & 0.178 & 0.118 & 0.081 & 0.051 & 0.025 & 0.090 \\
\hline 1973 & 0.002 & -0.054 & -0.051 & -0.068 & -0.036 & -0.041 \\
\hline 1974 & 0.211 & 0.168 & 0.103 & 0.049 & 0.007 & 0.108 \\
\hline 1975 & 0.387 & 0.340 & 0.251 & 0.237 & 0.149 & 0.273 \\
\hline 1976 & 0.283 & 0.209 & 0.173 & 0.168 & 0.136 & 0.194 \\
\hline 1977 & 0.078 & 0.043 & 0.009 & -0.006 & -0.042 & 0.016 \\
\hline 1978 & 0.001 & -0.009 & -0.035 & -0.051 & -0.059 & -0.031 \\
\hline 1979 & 0.137 & 0.118 & 0.077 & 0.066 & 0.050 & 0.090 \\
\hline 1980 & 0.147 & 0.076 & 0.062 & 0.042 & 0.060 & 0.077 \\
\hline 1981 & 0.041 & 0.020 & -0.002 & -0.023 & -0.037 & 0.000 \\
\hline 1982 & 0.012 & -0.030 & -0.044 & -0.046 & -0.023 & -0.026 \\
\hline 1983 & 0.117 & 0.081 & 0.052 & 0.043 & 0.030 & 0.064 \\
\hline 1984 & 0.052 & -0.003 & -0.003 & -0.021 & -0.013 & 0.002 \\
\hline 1985 & 0.180 & 0.145 & 0.111 & 0.112 & 0.075 & 0.125 \\
\hline 1986 & 0.048 & 0.027 & 0.012 & 0.019 & 0.024 & 0.026 \\
\hline 1987 & 0.125 & 0.098 & 0.127 & 0.125 & 0.125 & 0.120 \\
\hline 1988 & 0.093 & 0.065 & 0.041 & 0.047 & 0.050 & 0.059 \\
\hline 1989 & 0.073 & 0.042 & 0.055 & 0.051 & 0.063 & 0.057 \\
\hline 1990 & -0.032 & -0.080 & -0.085 & -0.077 & -0.075 & -0.070 \\
\hline 1991 & 0.106 & 0.086 & 0.084 & 0.067 & 0.051 & 0.079 \\
\hline 1992 & 0.161 & 0.138 & 0.079 & 0.047 & 0.002 & 0.086 \\
\hline 1993 & 0.110 & 0.063 & 0.042 & 0.031 & 0.016 & 0.052 \\
\hline 1994 & 0.066 & 0.062 & 0.035 & 0.029 & 0.029 & 0.044 \\
\hline 1995 & 0.051 & 0.049 & 0.005 & -0.006 & 0.021 & 0.024 \\
\hline 1996 & 0.044 & 0.018 & 0.017 & 0.000 & 0.021 & 0.020 \\
\hline 1997 & 0.106 & 0.059 & 0.038 & 0.021 & 0.034 & 0.052 \\
\hline 1998 & 0.028 & 0.004 & -0.010 & -0.006 & -0.014 & 0.000 \\
\hline 1999 & 0.123 & 0.073 & 0.037 & -0.004 & -0.009 & 0.044 \\
\hline 2000 & 0.128 & 0.059 & 0.024 & -0.021 & -0.038 & 0.030 \\
\hline 2001 & 0.232 & 0.221 & 0.164 & 0.066 & 0.007 & 0.138 \\
\hline 2002 & 0.073 & 0.040 & -0.011 & -0.019 & -0.013 & 0.014 \\
\hline 2003 & 0.042 & 0.010 & -0.022 & -0.024 & -0.024 & -0.004 \\
\hline 2004 & 0.099 & 0.080 & 0.056 & 0.030 & 0.020 & 0.057 \\
\hline 2005 & 0.000 & -0.038 & -0.051 & -0.031 & -0.026 & -0.029 \\
\hline \multicolumn{7}{|l|}{ uintile } \\
\hline mean & 0.097 & 0.063 & 0.037 & 0.020 & 0.012 & \\
\hline
\end{tabular}


Table $4 \quad$ FM regressions of annual holding returns on contemporaneous annual earnings levels and changes.

$R_{a, t}=\theta_{0}+\theta_{1} \frac{x_{a, t}}{P_{12 / 31, t-1}}+\theta_{2} \frac{x_{a, t}-x_{a, t-1}}{P_{12 / 31, t-1}}+\mu_{a, t} \quad$ Equation (14)

Panel A Annual coefficients from cross-sectional regressions, pooling all firm sizes.

\begin{tabular}{|c|c|c|c|c|c|}
\hline Year & $\boldsymbol{\theta}_{0}$ & $\theta_{1}$ & $\boldsymbol{\theta}_{2}$ & Adj. $R^{2}$ & \# obs. \\
\hline 1973 & -0.345 & 0.855 & 0.563 & 0.070 & 620 \\
\hline 1974 & -0.367 & 0.920 & 0.174 & 0.366 & 783 \\
\hline 1975 & 0.383 & 0.887 & 0.290 & 0.208 & 985 \\
\hline 1976 & 0.207 & 1.252 & 0.363 & 0.316 & 963 \\
\hline 1977 & 0.002 & 0.712 & 0.255 & 0.145 & 1,057 \\
\hline 1978 & -0.006 & 0.776 & 0.297 & 0.156 & 1,060 \\
\hline 1979 & 0.258 & 0.265 & 1.578 & 0.181 & 1,031 \\
\hline 1980 & 0.218 & 0.546 & 0.501 & 0.102 & 1,015 \\
\hline 1981 & -0.032 & 0.845 & 0.271 & 0.213 & 990 \\
\hline 1982 & 0.283 & 0.280 & 0.906 & 0.124 & 965 \\
\hline 1983 & 0.279 & 0.445 & 0.660 & 0.182 & 982 \\
\hline 1984 & -0.074 & 0.956 & 0.088 & 0.232 & 1,152 \\
\hline 1985 & 0.272 & 0.876 & 0.300 & 0.178 & 1,193 \\
\hline 1986 & 0.067 & 0.808 & 0.270 & 0.217 & 1,232 \\
\hline 1987 & -0.078 & 0.719 & 0.347 & 0.161 & 1,220 \\
\hline 1988 & 0.173 & 0.730 & 0.336 & 0.133 & 1,239 \\
\hline 1989 & 0.214 & 0.375 & 0.673 & 0.115 & 1,293 \\
\hline 1990 & -0.160 & 0.789 & 0.195 & 0.108 & 1,316 \\
\hline 1991 & 0.453 & 0.450 & 0.662 & 0.071 & 1,361 \\
\hline 1992 & 0.156 & 0.868 & 0.928 & 0.183 & 1,416 \\
\hline 1993 & 0.176 & 0.863 & 0.696 & 0.108 & 1,544 \\
\hline 1994 & -0.018 & 0.406 & 0.681 & 0.083 & 1,675 \\
\hline 1995 & 0.331 & 0.480 & 0.771 & 0.044 & 1,994 \\
\hline 1996 & 0.166 & 0.971 & 0.440 & 0.117 & 2,246 \\
\hline 1997 & 0.233 & 1.708 & 0.165 & 0.149 & 2,297 \\
\hline 1998 & -0.011 & 0.509 & 0.645 & 0.055 & 2,422 \\
\hline 1999 & 0.324 & -1.441 & 1.927 & 0.041 & 2,463 \\
\hline 2000 & 0.054 & 0.991 & 0.373 & 0.076 & 2,493 \\
\hline 2001 & 0.261 & 0.544 & 0.949 & 0.094 & 2,505 \\
\hline 2002 & -0.092 & 1.373 & 0.454 & 0.159 & 2,502 \\
\hline 2003 & 0.602 & -0.149 & 1.497 & 0.071 & 2,535 \\
\hline 2004 & 0.174 & 0.913 & 0.692 & 0.110 & 2,559 \\
\hline 2005 & 0.053 & 1.058 & 0.479 & 0.087 & $\frac{2,475}{51,583}$ \\
\hline Mean FM coefficient & $0.126 * *$ & $0.684 * * *$ & $0.589 * * *$ & 0.141 & \\
\hline Std error & 0.037 & 0.090 & 0.073 & & \\
\hline t-stat & 3.439 & 7.616 & 8.059 & & \\
\hline
\end{tabular}

* significant at $\alpha<0.05,1$-tail test

** significant at $\alpha<0.001,1$-tail test

$* * *$ significant at $\alpha<0.0001,1$-tail test 
Table 4, continued

Panel B Mean FM coefficients from annual cross-sectional regressions, for smallest and largest quintiles.

\begin{tabular}{clllcc} 
Quintile & \multicolumn{1}{c}{$\boldsymbol{\theta}_{\mathbf{0}}$} & \multicolumn{1}{c}{$\boldsymbol{\theta}_{\mathbf{1}}$} & $\boldsymbol{\theta}_{\mathbf{2}}$ & Mean Adj. $\mathbf{R}^{\mathbf{2}}$ & \# obs. \\
1 & $0.224 * * *$ & $0.781 * * *$ & $0.472 * * *$ & 0.151 & 9,661 \\
5 & $0.064 *$ & $0.685 * *$ & $0.886 *$ & 0.148 & 11,329 \\
Difference in means & $0.160 * * *$ & 0.096 & -0.414 &
\end{tabular}

Differences in means analyzed by running FM regressions for each quintile of firm size and conducting paired t-tests of the 33 annual coefficients in each size group.

* significant at $\alpha<0.05,1$-tail test

** significant at $\alpha<0.001,1$-tail test

*** significant at $\alpha<0.0001,1$-tail test 
Table 5 FM regressions of quarterly holding returns on contemporaneous quarterly earnings levels and changes, all four quarters combined.

$R_{q n, t}=\theta_{0}+\theta_{1} \frac{x_{q n, t}}{P_{x q n, t-1}}+\theta_{2} \frac{x_{q n, t}-x_{q n, t-1}}{P_{x q n, t-1}}+\mu_{q n, t} \quad$ Equation (15), $n=1,2,3$ and 4

Panel A Annual coefficients from cross-sectional regressions, pooling all firm sizes.

\begin{tabular}{|c|c|c|c|c|c|}
\hline Year & $\boldsymbol{\theta}_{0}$ & $\theta_{1}$ & $\theta_{2}$ & Adj. $\mathbf{R}^{2}$ & \# obs. \\
\hline 1973 & -0.072 & 0.161 & 0.292 & 0.007 & 2,469 \\
\hline 1974 & -0.063 & 0.278 & 0.211 & 0.026 & 3,104 \\
\hline 1975 & 0.129 & 0.185 & -0.029 & 0.002 & 3,946 \\
\hline 1976 & 0.095 & 0.148 & 0.487 & 0.026 & 3,851 \\
\hline 1977 & 0.022 & 0.137 & 0.327 & 0.025 & 4,221 \\
\hline 1978 & 0.031 & 0.193 & 0.041 & 0.005 & 4,227 \\
\hline 1979 & 0.075 & -0.018 & 0.599 & 0.035 & 4,131 \\
\hline 1980 & 0.065 & 0.206 & 0.052 & 0.009 & 4,054 \\
\hline 1981 & 0.016 & 0.154 & 0.119 & 0.011 & 3,947 \\
\hline 1982 & 0.070 & -0.054 & 0.345 & 0.012 & 3,870 \\
\hline 1983 & 0.078 & 0.122 & 0.156 & 0.007 & 3,929 \\
\hline 1984 & -0.007 & 0.444 & 0.005 & 0.032 & 4,565 \\
\hline 1985 & 0.075 & 0.139 & 0.213 & 0.018 & 4,751 \\
\hline 1986 & 0.028 & 0.262 & 0.060 & 0.013 & 4,877 \\
\hline 1987 & 0.003 & 0.423 & 0.066 & 0.015 & 4,865 \\
\hline 1988 & 0.054 & 0.224 & 0.139 & 0.016 & 4,948 \\
\hline 1989 & 0.052 & 0.150 & 0.339 & 0.027 & 5,123 \\
\hline 1990 & -0.034 & 0.471 & 0.046 & 0.024 & 5,217 \\
\hline 1991 & 0.100 & 0.403 & 0.003 & 0.013 & 5,468 \\
\hline 1992 & 0.047 & 0.142 & 0.268 & 0.017 & 5,677 \\
\hline 1993 & 0.047 & 0.336 & 0.145 & 0.014 & 6,175 \\
\hline 1994 & -0.003 & 0.393 & 0.216 & 0.021 & 6,657 \\
\hline 1995 & 0.076 & 0.142 & 0.246 & 0.008 & 7,926 \\
\hline 1996 & 0.047 & 0.275 & 0.166 & 0.011 & 8,936 \\
\hline 1997 & 0.065 & 0.890 & 0.167 & 0.035 & 9,174 \\
\hline 1998 & 0.008 & 0.142 & 0.160 & 0.004 & 9,670 \\
\hline 1999 & 0.063 & -0.449 & 0.468 & 0.006 & 9,821 \\
\hline 2000 & 0.030 & 0.338 & 0.281 & 0.010 & 9,874 \\
\hline 2001 & 0.075 & -0.275 & 0.451 & 0.009 & 9,997 \\
\hline 2002 & -0.007 & 0.198 & 0.107 & 0.006 & 10,008 \\
\hline 2003 & 0.134 & -0.532 & 0.491 & 0.017 & 10,139 \\
\hline 2004 & 0.051 & 0.341 & 0.262 & 0.012 & 10,200 \\
\hline 2005 & 0.020 & 0.464 & 0.188 & 0.016 & $\begin{array}{r}9,845 \\
05662\end{array}$ \\
\hline Mean & $0.042 * * *$ & $0.195 * * *$ & $0.215 * * *$ & 0.015 & 062 \\
\hline Std error & 0.008 & 0.046 & 0.028 & & \\
\hline t-stat & 5.032 & 4.265 & 7.791 & & \\
\hline
\end{tabular}

* $\quad$ significant at $\alpha<0.05,1$-tail test

** significant at $\alpha<0.001,1$-tail test

$* * *$ significant at $\alpha<0.0001,1$-tail test 
Table 5, continued

Panel B Mean FM coefficients from quarterly cross-sectional regressions, for smallest and largest quintiles.

$\begin{array}{clllcc}\text { Quintile } & \boldsymbol{\theta}_{\mathbf{0}} & \boldsymbol{\theta}_{\mathbf{1}} & \boldsymbol{\theta}_{\mathbf{2}} & \text { Mean Adj. } \mathbf{R}^{2} & \text { \# obs. } \\ 1 & 0.065 * * * & 0.277 * * * & 0.175 * * * & 0.018 & 38,184 \\ 5 & 0.023 * & 0.396 * * & 0.210 & 0.019 & 45,291 \\ \text { Difference in means } & 0.043 * * * & -0.119 & -0.035 & \end{array}$

Differences in means analyzed by running FM regressions for each quintile of firm size and conducting paired t-tests of the 33 annual coefficients in each size group.

* $\quad$ significant at $\alpha<0.05,1$-tail test

** significant at $\alpha<0.001,1$-tail test

$* * *$ significant at $\alpha<0.0001,1$-tail test 
Table 6

FM coefficients from benchmark testing of returns-earnings association for quarters two, three and four.

Quintile 1 firms.

Panel A First-month holding returns and quarterly earnings.

April returns-q2 earnings: $\quad R_{4, t}=\theta_{0}+\theta_{1} \frac{x_{q 2, t}}{P_{03 / 31 / t}}+\theta_{2} \frac{x_{q 2, t}-x_{q 2, t-1}}{P_{03 / 31 / t}}+\mu_{t} \quad$ Equation (16) July returns-q3 earnings: $\quad R_{7, t}=\theta_{0}+\theta_{1} \frac{x_{q 3, t}}{P_{06 / 30 / t}}+\theta_{2} \frac{x_{q 3, t}-x_{q 3, t-1}}{P_{06 / 30 / t}}+\mu_{t} \quad$ Equation (17) October returns-q4 earnings: $\quad R_{10, t}=\theta_{0}+\theta_{1} \frac{x_{q 10, t}}{P_{09 / 30 / t}}+\theta_{2} \frac{x_{q 10, t}-x_{q 10, t-1}}{P_{09 / 30 / t}}+\mu_{t}$ Equation (18)

$\begin{array}{lccccc} & \boldsymbol{\theta}_{\mathbf{0}} & \boldsymbol{\theta}_{\mathbf{1}} & \boldsymbol{\theta}_{\mathbf{2}} & \text { Mean Adj. } \mathbf{R}^{\mathbf{2}} & \text { \# obs. } \\ \text { April returns-q2 earnings } & 0.018 * & 0.213 * * * & 0.068 * & 0.017 & 9,779 \\ \text { July returns-q3 earnings } & 0.013 & 0.177 * * * & 0.083 * * & 0.020 & 9,760 \\ \text { October returns-q4 earnings } & -0.008 & 0.153 * * * & 0.019 & 0.016 & 8,846\end{array}$

* $\quad$ significant at $\alpha<0.05,1$-tail test

** $\quad$ significant at $\alpha<0.001,1$-tail test

$* * *$ significant at $\alpha<0.0001,1$-tail test

\section{Panel B Quarterly holding returns and quarterly earnings.}

q2 returns-q2 earnings: $R_{q 2, t}=\theta_{0}+\theta_{1} \frac{x_{q 2, t}}{P_{03 / 31 / t}}+\theta_{2} \frac{x_{q 2, t}-x_{q 2, t-1}}{P_{03 / 31 / t}}+\mu_{q 2, t} \quad$ Equation (19)

q3 returns-q3 earnings: $R_{q 3, t}=\theta_{0}+\theta_{1} \frac{x_{q 3, t}}{P_{06 / 30 / t}}+\theta_{2} \frac{x_{q 3, t}-x_{q 3, t-1}}{P_{06 / 30 / t}}+\mu_{q 3, t} \quad$ Equation (20) q4 returns-q4 earnings: $R_{q 4, t}=\theta_{0}+\theta_{1} \frac{x_{q 4, t}}{P_{09 / 30 / t}}+\theta_{2} \frac{x_{q 4, t}-x_{q 4, t-1}}{P_{09 / 30 / t}}+\mu_{q 4, t} \quad$ Equation (21)

$\begin{array}{llccc} & \boldsymbol{\theta}_{\mathbf{0}} & \boldsymbol{\theta}_{\mathbf{1}} & \boldsymbol{\theta}_{\mathbf{2}} & \text { Mean Adj. } \mathbf{R}^{\mathbf{2}} \\ \text { q2 returns-q2 earnings } & 0.056 * & 0.465 * * * & 0.203 * * & 0.042 \\ \text { q3 returns-q3 earnings } & 0.011 & 0.441 * * * & 0.208 * & 0.037 \\ \text { q4 returns-q4 earnings } & 0.021 & 0.356 * * * & 0.046 & 0.033\end{array}$

* $\quad$ significant at $\alpha<0.05,1$-tail test

** significant at $\alpha<0.001,1$-tail test

$* * *$ significant at $\alpha<0.0001,1$-tail test 
Table 7 Mean FM coefficients for January (first quarter) returns and first quarter earnings. Coefficients of corresponding regressions for quarters two, three and four are provided for comparison.

Quintile 1 firms.

Panel A Test of H1: January returns in year $(t)$ are positively associated with earnings level and earnings change for $q 1$ of year ( $t)$.

$$
R_{m 1, t}=\theta_{0}+\theta_{1} \frac{x_{q 1, t}}{P_{12 / 31 / t-1}}+\theta_{2} \frac{x_{q 1, t}-x_{q 1, t-1}}{P_{12 / 31 / t-1}}+\mu_{t} \quad \text { Equation (11) }
$$

\begin{tabular}{|c|c|c|c|c|c|}
\hline Month - Quarter & $\boldsymbol{\theta}_{0}$ & $\boldsymbol{\theta}_{1}$ & $\boldsymbol{\theta}_{2}$ & Mean Adj. $\mathbf{R}^{2}$ & \# obs. \\
\hline January - quarter 1 & $0.100 * * *$ & $-0.139^{\dagger}$ & $0.241 * * *$ & 0.020 & 9,799 \\
\hline April-quarter 2 & $0.018 *$ & $0.213 * * *$ & $0.068 *$ & 0.017 & 9,779 \\
\hline July-quarter 3 & 0.013 & $0.177 * * *$ & $0.083 *$ & 0.020 & 9,760 \\
\hline October-quarter 4 & -0.008 & $0.153 * * *$ & 0.019 & 0.016 & 8,846 \\
\hline \multicolumn{6}{|c|}{ * $\quad$ significant at $\alpha<0.05,1$-tail test } \\
\hline \multicolumn{6}{|c|}{ ** significant at $\alpha<0.001,1$-tail test } \\
\hline$* * *$ significant at $\alpha<0$. & 1-tail test & & & & \\
\hline
\end{tabular}




\section{Table 7, continued}

Panel B First-quarter holding returns and first-quarter earnings levels and changes.

Coefficients of corresponding regressions for quarters two, three and four are provided for comparison.

$$
R_{q 1, t}=\theta_{0}+\theta_{1} \frac{x_{q 1, t}}{P_{12 / 31 / t-1}}+\theta_{2} \frac{x_{q 1, t}-x_{q 1, t-1}}{P_{12 / 31 / t-1}}+\mu_{q 1, t} \quad \text { Equation (15) with } n=1
$$

$\begin{array}{clllc}\text { Quarter } & \boldsymbol{\theta}_{\mathbf{0}} & \boldsymbol{\theta}_{\mathbf{1}} & \boldsymbol{\theta}_{\mathbf{2}} & \text { Mean Adj. } \mathbf{R}^{\mathbf{2}} \\ 1 & 0.161 * * * & 0.016 & 0.596 * * * & 0.028 \\ 2 & 0.056 * & 0.465 * * * & 0.203 * * & 0.042 \\ 3 & 0.011 & 0.441 * * * & 0.208 * & 0.037 \\ 4 & 0.021 & 0.356 * * * & 0.046 & 0.033\end{array}$

* $\quad$ significant at $\alpha<0.05,1$-tail test

** $\quad$ significant at $\alpha<0.001,1$-tail test

$* * *$ significant at $\alpha<0.0001,1$-tail test 
Table 8 Paired t-tests to determine significance of differences between FM coefficients in Table 7 across all four quarters. Applying a Bonferroni adjustment for this family of tests, with 6 pairings on each coefficient gives a t-statistic of 2.85 for $\alpha=0.05$.

Panel A Paired t-tests of the 33 annual FM coefficients in Table 7, Panel A - the regressions of firstmonth returns on contemporaneous quarterly earnings.

$t$-statistics appear in parentheses. Bolded items are significant at a level of $\alpha \leq 0.05$.

\begin{tabular}{|c|c|c|c|c|c|c|}
\hline$\theta_{0}$ (Intercept) & $\begin{array}{c}\text { Qtr. 1 } \\
\text { vs. } \\
\text { Qtr. } 2\end{array}$ & $\begin{array}{c}\text { Qtr. 1 } \\
\text { vs. } \\
\text { Qtr. } 3\end{array}$ & $\begin{array}{c}\text { Qtr. 1 } \\
\text { vs. } \\
\text { Qtr. } 4\end{array}$ & $\begin{array}{c}\text { Qtr. } 2 \\
\text { vs. } \\
\text { Qtr. 3 }\end{array}$ & $\begin{array}{c}\text { Qtr. } 2 \\
\text { vs. } \\
\text { Qtr. } 4\end{array}$ & $\begin{array}{c}\text { Qtr. 3 } \\
\text { vs. } \\
\text { Qtr. } 4\end{array}$ \\
\hline Difference in means & $\begin{array}{l}0.082 \\
(4.67)\end{array}$ & $\begin{array}{l}\mathbf{0 . 0 8 7} \\
(5.28)\end{array}$ & $\begin{array}{l}0.108 \\
(5.45)\end{array}$ & $\begin{array}{l}0.005 \\
(0.44)\end{array}$ & $\begin{array}{l}0.026 \\
(1.53)\end{array}$ & $\begin{array}{l}0.021 \\
(1.20)\end{array}$ \\
\hline $\begin{array}{c}\boldsymbol{\theta}_{\boldsymbol{l}} \\
\text { Difference in means }\end{array}$ & $\begin{array}{l}-0.351 \\
(-4.58)\end{array}$ & $\begin{array}{l}-0.316 \\
(-4.05)\end{array}$ & $\begin{array}{l}-0.292 \\
(-4.27)\end{array}$ & $\begin{array}{l}0.036 \\
(0.62)\end{array}$ & $\begin{array}{l}0.060 \\
(1.46)\end{array}$ & $\begin{array}{l}0.024 \\
(0.62)\end{array}$ \\
\hline $\begin{array}{c}\boldsymbol{\theta}_{2} \\
\text { Difference in means }\end{array}$ & $\begin{array}{l}0.174 \\
(2.91)\end{array}$ & $\begin{array}{l}0.159 \\
(2.76)\end{array}$ & $\begin{array}{l}0.222 \\
(4.56)\end{array}$ & $\begin{array}{l}-0.015 \\
(-0.32)\end{array}$ & $\begin{array}{l}0.048 \\
(1.47)\end{array}$ & $\begin{array}{l}0.063 \\
(1.76)\end{array}$ \\
\hline
\end{tabular}


Table 8, continued

Panel B Paired t-tests of the 33 annual FM coefficients in Table 7, Panel B - the regressions of quarterly returns on contemporaneous quarterly earnings.

t-statistics appear in parentheses. Bolded items are significant at a level of $\alpha \leq 0.05$.

\begin{tabular}{|c|c|c|c|c|c|c|}
\hline$\theta_{0}($ Intercept $)$ & $\begin{array}{c}\text { Qtr. } 1 \\
\text { vs. } \\
\text { Qtr. } 2\end{array}$ & $\begin{array}{c}\text { Qtr. } 1 \\
\text { vs. } \\
\text { Qtr. } 3\end{array}$ & $\begin{array}{c}\text { Qtr. } 1 \\
\text { vs. } \\
\text { Qtr. } 4\end{array}$ & $\begin{array}{c}\text { Qtr. } 2 \\
\text { vs. } \\
\text { Qtr. } 3\end{array}$ & $\begin{array}{c}\text { Qtr. } 2 \\
\text { vs. } \\
\text { Qtr. } 4\end{array}$ & $\begin{array}{l}\text { Qtr. 3 } \\
\text { vs. } \\
\text { Qtr. } 4\end{array}$ \\
\hline Difference in means & $\begin{array}{l}0.105 \\
(3.32)\end{array}$ & $\begin{array}{l}0.149 \\
(3.91)\end{array}$ & $\begin{array}{l}0.140 \\
(4.12)\end{array}$ & $\begin{array}{l}0.044 \\
(1.79)\end{array}$ & $\begin{array}{l}0.035 \\
(1.42)\end{array}$ & $\begin{array}{l}-0.010 \\
(-0.30)\end{array}$ \\
\hline $\begin{array}{c}\boldsymbol{\theta}_{\boldsymbol{1}} \\
\text { Difference in means }\end{array}$ & $\begin{array}{l}-0.449 \\
(-3.16)\end{array}$ & $\begin{array}{l}-0.425 \\
(-3.30)\end{array}$ & $\begin{array}{l}-0.341 \\
(-3.17)\end{array}$ & $\begin{array}{l}0.024 \\
(0.21)\end{array}$ & $\begin{array}{l}0.108 \\
(1.12)\end{array}$ & $\begin{array}{l}0.085 \\
(1.06)\end{array}$ \\
\hline $\begin{array}{c}\boldsymbol{\theta}_{2} \\
\text { Difference in means }\end{array}$ & $\begin{array}{l}0.393 \\
(3.18)\end{array}$ & $\begin{array}{l}0.388 \\
(3.10)\end{array}$ & $\begin{array}{l}0.550 \\
(6.03)\end{array}$ & $\begin{array}{l}-0.005 \\
(-0.07)\end{array}$ & $\begin{array}{l}0.157 \\
(2.08)\end{array}$ & $\begin{array}{l}0.162 \\
(2.04)\end{array}$ \\
\hline
\end{tabular}


Table 9 Mean coefficients for FM regressions of holding returns for the last 2 months of each quarter and quarterly earnings.

Quintile 1 firms.

$\begin{array}{lc}\text { Months - Quarter } & \boldsymbol{\theta}_{\mathbf{0}} \\ \text { Feb \& Mar - quarter 1 } & 0.057 * \\ \text { May \& Jun - quarter 2 } & 0.037 * \\ \text { Aug \& Sep - quarter 3 } & -0.002 \\ \text { Nov \& Dec - quarter 4 } & 0.030 * \\ \text { * } & \text { significant at } \alpha<0.05,1 \text {-tail test } \\ * * & \text { significant at } \alpha<0.001,1 \text {-tail test } \\ * * * & \text { significant at } \alpha<0.0001,1 \text {-tail test }\end{array}$

$\boldsymbol{\theta}_{1}$

$0.134 *$

$0.223 * *$

$0.245 * *$

$0.207 * * *$
Mean Adj. $\mathbf{R}^{2}$

0.018

0.021

0.022

0.019

$0.117 *$

0.016
\# obs.

9,799

9,779

9,760

8,846

** significant at $\alpha<0.001,1$-tail test

*** significant at $\alpha<0.0001,1$-tail test 
Table 10 Mean FM coefficients from regressing January returns in year $(t)$ on annual and fourth-quarter earnings from year $(t-1)$.

Quintile 1 firms.

Panel A Test of H3: January returns in year $(t)$ are positively associated with level and change in earnings of year $(t-1)$.
$R_{m 1, t}=\theta_{0}+\theta_{1} \frac{x_{a, t-1}}{P_{12 / 31 / t-2}}+\theta_{2} \frac{x_{a, t-1}-x_{a, t-2}}{P_{12 / 31 / t-2}}+\mu_{t}$
Equation (12)
$\operatorname{Jan}(t)-\operatorname{annual}(t-1)$
$\boldsymbol{\theta}_{0}$
$0.101 * * *$
$\boldsymbol{\theta}_{1}$
$-0.130^{\dagger}$
$\boldsymbol{\theta}_{2}$
$0.104 * * *$
$\begin{array}{cc}\text { Mean Adj. } \mathbf{R}^{2} & \# \text { obs. } \\ 0.021 & 7,273\end{array}$
* $\quad$ significant at $\alpha<0.05,1$-tail test
** $\quad$ significant at $\alpha<0.001,1$-tail test
$* * *$ significant at $\alpha<0.0001,1$-tail test
$\dagger$ p-value $<0.0001$ in a 1-tail test of $\theta_{1}<0$.

Panel B Test of H4: January returns in year $(t)$ are positively associated with level and change in earnings of quarter four in year $(t-1)$.
$R_{m 1, t}=\theta_{0}+\theta_{1} \frac{x_{q 4, t-1}}{P_{09 / 30 / t-1}}+\theta_{2} \frac{x_{q 4, t-1}-x_{q 3, t-1}}{P_{09 / 30 / t-1}}+\mu_{t} \quad$ Equation (13)
$\operatorname{Jan}(t)-\mathrm{q} 4(t-1)$
$\begin{array}{cc}\boldsymbol{\theta}_{\mathbf{0}} & \boldsymbol{\theta}_{\mathbf{1}} \\ 0.091 * * * & -0.117^{\dagger}\end{array}$
$\boldsymbol{\theta}_{2}$
$0.160 * * *$
Mean Adj. $\mathbf{R}^{2}$
0.022
\# obs.
6,932
* $\quad$ significant at $\alpha<0.05,1$-tail test
** significant at $\alpha<0.001,1$-tail test
$* * *$ significant at $\alpha<0.0001,1$-tail test
$\dagger$ p-value $=0.012$ in a 1 -tail test of $\theta_{1}<0$ 
Table 10, continued

Panel C Robustness tests for H4: Regressions of April (July/October) returns in year ( $t$ ) on earnings of the previous quarter, provided for comparison with results in Panel B.

$$
\begin{aligned}
& R_{m 4, t}=\theta_{0}+\theta_{1} \frac{x_{q 1, t}}{P_{12 / 31 / t-1}}+\theta_{2} \frac{x_{q 1, t}-x_{q, t-1}}{P_{12 / 31 / t-1}}+\mu_{t} \\
& R_{m 7, t}=\theta_{0}+\theta_{1} \frac{x_{q 2, t}}{P_{03 / 31 / t}}+\theta_{2} \frac{x_{q 2, t}-x_{q 2, t-1}}{P_{03 / 31 / t}}+\mu_{t} \\
& R_{m 10, t}=\theta_{0}+\theta_{1} \frac{x_{q 3, t}}{P_{06 / 30 / t}}+\theta_{2} \frac{x_{q 3, t}-x_{q 3, t-1}}{P_{06 / 30 / t}}+\mu_{t}
\end{aligned}
$$

$\begin{array}{lccccc} & \boldsymbol{\theta}_{\mathbf{0}} & \boldsymbol{\theta}_{\mathbf{1}} & \boldsymbol{\theta}_{\mathbf{2}} & \text { Mean Adj. } \mathbf{R}^{\mathbf{2}} & \text { \# obs. } \\ \operatorname{Apr}(t)-\mathrm{q} 1(t) & 0.023 * & 0.226 * * & 0.141 * & 0.037 & 9,690 \\ \operatorname{Jul}(t)-\mathrm{q} 2(t) & 0.009 & 0.227 * * & 0.081 * & 0.029 & 9,670 \\ \operatorname{Oct}(t)-\mathrm{q} 3(t) & -0.012 & 0.215 * * & 0.134 * & 0.030 & 9,653\end{array}$

* $\quad$ significant at $\alpha<0.05,1$-tail test

$* *$ significant at $\alpha<0.001,1$-tail test

$* * *$ significant at $\alpha<0.0001,1$-tail test 
Table 11 Summary statistics for the full sample, partitioned according to January effect (JE) firms and non-January effect (NJE) firms.

JE firms are firms whose January return in year $t$ is higher than the mean of the returns for the other 11 months in the year.

Panel A Number of firms and mean January return in each partition subset.

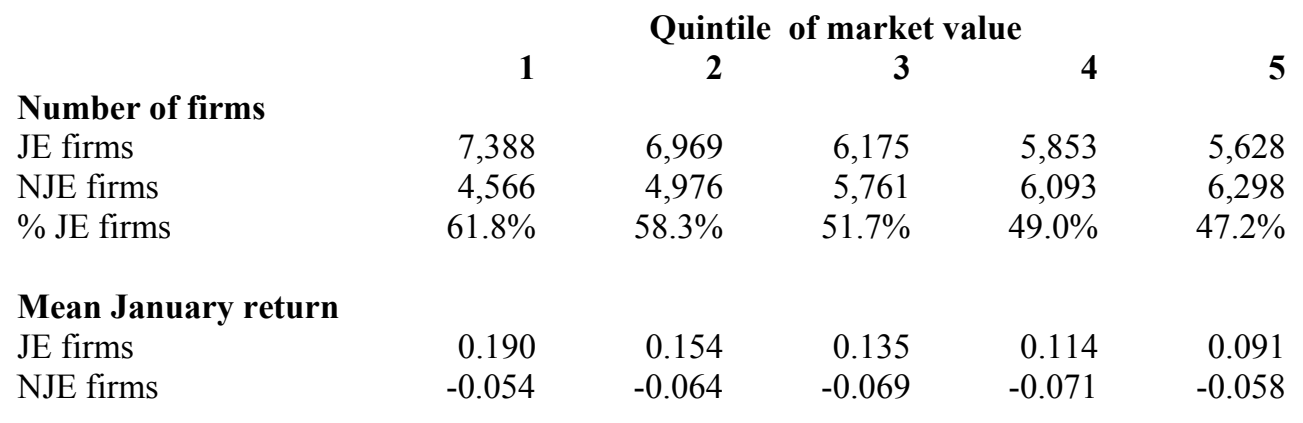

Panel B Beginning-of-year share price (\$), cumulatively adjusted for stock splits and dividends, in each partition subset.

\begin{tabular}{lrrrrr} 
& \multicolumn{5}{c}{ Quintile of market value } \\
JE firms & \multicolumn{1}{c}{} & $\mathbf{2}$ & $\mathbf{3}$ & $\mathbf{4}$ & \multicolumn{1}{c}{$\mathbf{5}$} \\
Mean & 7.644 & 11.223 & 14.613 & 34.019 & 58.160 \\
Std. dev. & 86.057 & 51.933 & 43.450 & 802.093 & 1594.710 \\
Upper quartile & 7.125 & 12.250 & 17.000 & 22.250 & 29.560 \\
Median & 4.000 & 7.490 & 10.750 & 14.250 & 18.130 \\
Lower quartile & 2.250 & 4.250 & 5.938 & 7.847 & 9.970 \\
& & & & & \\
NJE firms & & & & & \\
Mean & 9.222 & 24.980 & 15.739 & 31.503 & 92.750 \\
Std. dev. & 69.118 & 488.297 & 22.634 & 547.365 & 1995.430 \\
Upper quartile & 9.165 & 13.600 & 18.750 & 25.125 & 33.420 \\
Median & 5.062 & 8.600 & 12.323 & 16.553 & 21.320 \\
Lower quartile & 2.843 & 4.875 & 7.250 & 9.311 & 11.440
\end{tabular}


Table 11, continued

Panel C SEPS scaled by beginning-of-year price, cumulatively adjusted for stock splits and dividends, for each subset.

Quintile 1 firms only.

\begin{tabular}{|c|c|c|}
\hline & JE firms & NJE firms \\
\hline \multicolumn{3}{|l|}{ Annual \$EPS } \\
\hline Mean & -7.301 & -0.054 \\
\hline Std. dev. & 517.590 & 6.803 \\
\hline Upper quartile & 0.140 & 0.132 \\
\hline Median & 0.059 & 0.065 \\
\hline Lower quartile & -0.040 & -0.005 \\
\hline \multicolumn{3}{|c|}{ Quarter 1 \$EPS } \\
\hline Mean & -0.151 & -0.067 \\
\hline Std. dev. & 7.615 & 4.002 \\
\hline Upper quartile & 0.031 & 0.027 \\
\hline Median & 0.013 & 0.013 \\
\hline Lower quartile & -0.008 & -0.004 \\
\hline \multicolumn{3}{|l|}{ Quarter 2 SEPS } \\
\hline Mean & 0.151 & -0.024 \\
\hline Std. dev. & 9.692 & 1.693 \\
\hline Upper quartile & 0.040 & 0.036 \\
\hline Median & 0.018 & 0.018 \\
\hline Lower quartile & 0.000 & 0.002 \\
\hline \multicolumn{3}{|l|}{ Quarter 3 \$EPS } \\
\hline Mean & 0.065 & 0.141 \\
\hline Std. dev. & 5.621 & 4.187 \\
\hline Upper quartile & 0.039 & 0.037 \\
\hline Median & 0.017 & 0.018 \\
\hline Lower quartile & -0.004 & 0.002 \\
\hline \multicolumn{3}{|c|}{ Quarter 4 SEPS } \\
\hline Mean & -7.366 & -0.095 \\
\hline Std. dev. & 526.988 & 4.506 \\
\hline Upper quartile & 0.043 & 0.039 \\
\hline Median & 0.015 & 0.017 \\
\hline Lower quartile & -0.021 & -0.006 \\
\hline
\end{tabular}


Table 12 Comparison of JE firms to NJE firms for regression of January returns on first-quarter earnings using FM regression methodology.

Quintile 1 firms.

$$
R_{m 1, t}=\theta_{0}+\theta_{1} \frac{x_{q 1, t}}{P_{12 / 31 / t-1}}+\theta_{2} \frac{x_{q 1, t}-x_{q 1, t-1}}{P_{12 / 31 / t-1}}+\mu_{t} \quad \text { Equation (11) }
$$

$\begin{array}{lccccc} & \boldsymbol{\theta}_{\mathbf{0}} & \boldsymbol{\theta}_{\mathbf{1}} & \boldsymbol{\theta}_{\mathbf{2}} & \text { Mean Adj. } \mathbf{R}^{\mathbf{2}} & \text { \# obs. } \\ \text { JE firms } & 0.173 * * & -0.221^{\dagger} & 0.322 * * & 0.027 & 6,064 \\ \text { NJE firms } & -0.053^{*} & 0.292 * & -0.029 & 0.047 & 3,723\end{array}$

* $\quad$ significant at $\alpha<0.05,1$-tail test

** $\quad$ significant at $\alpha<0.001,1$-tail test

$* * *$ significant at $\alpha<0.0001,1$-tail test

$\dagger \mathrm{p}$-value $=0.0021$ in a 1 -tail test of $\theta_{1}<0$

p-value $<0.0001$ in a 1 -tail test of $\theta_{0}<0$ 
Table 13 Robustness tests using book value as a conditioning variable in regressions of first-month returns on quarterly earnings.

Quintile 1 firms.

Panel A Mean Pearson correlations between variables. As in Penman and Yehuda (2006), values are means of annual cross-sectional correlations over all years in the sample period.

Quarter

$$
\left[R_{1^{s t} \text { month }}, \frac{x_{q n}}{P_{q n-1}}\right]
$$

1

2

3

4

$$
-0.006
$$

$0.163 * *$

0.126

0.119
$\left[R_{1^{s t} \text { month }}, \frac{b_{q n-1}}{P_{q n-1}}\right]$

$-0.036 *$

0.035

0.047

0.022 $\left[\frac{x_{q n}}{P_{x, q n-1}}, \frac{b_{q n-1}}{P_{x, q n-1}}\right]$

0.074 *

0.064 *

0.023

$-0.021$

* $\quad$ significant at $\alpha<0.05,2$-tail test

** significant at $\alpha<0.001,2$-tail test

$* * *$ significant at $\alpha<0.0001,2$-tail test 
Table 13, continued

Panel B Comparison of coefficient results for regressions of first-month returns on quarterly earnings using PY2006 for all four quarters.

$$
\begin{array}{ll}
R_{m 1, t}=a_{0}+a_{1} \frac{x_{q 1 t}}{P_{12 / 31 / t-1}}+a_{2} \frac{b_{q 4}}{P_{12 / 31 / t-1}}+\varepsilon_{t} & \text { Equation (22) } \\
R_{m 4, t}=a_{0}+a_{1} \frac{x_{q 2 t}}{P_{03 / 31 / t}}+a_{2} \frac{b_{q 1}}{P_{03 / 31 / t}}+\varepsilon_{t} & \text { Equation (23) } \\
R_{m 7, t}=a_{0}+a_{1} \frac{x_{q 3 t}}{P_{06 / 30 / t}}+a_{2} \frac{b_{q 2}}{P_{06 / 30 / t}}+\varepsilon_{t} & \text { Equation (24) } \\
R_{m 10, t}=a_{0}+a_{1} \frac{x_{q 4 t}}{P_{09 / 30 / t}}+a_{2} \frac{b_{q 3}}{P_{09 / 30 / t}}+\varepsilon_{t} & \text { Equation (25) }
\end{array}
$$

\begin{tabular}{lccccc}
\multicolumn{1}{r}{ Month - Quarter } & $\mathbf{a}_{\mathbf{0}}$ & $\mathbf{a}_{\mathbf{1}}$ & $\mathbf{a}_{2}$ & Mean Adj. $\mathbf{R}^{\mathbf{2}}$ & $\#$ obs. \\
January - quarter 1 & $0.099 * * *$ & -0.065 & -0.011 & 0.007 & 7,178 \\
April - quarter 2 & 0.001 & $0.554 * * *$ & 0.010 & 0.040 & 9,454 \\
July - quarter 3 & -0.006 & $0.355 * * *$ & $0.013 *$ & 0.027 & 9,538 \\
October - quarter 4 & -0.021 & $0.248 * * *$ & 0.005 & 0.017 & 8,495
\end{tabular}

* $\quad$ significant at $\alpha<0.05,1$-tail test

** significant at $\alpha<0.001,1$-tail test

$* * *$ significant at $\alpha<0.0001,1$-tail test 
Table 13, continued

Panel C Comparison of "January effect" firms to "non-January effect" firms for regressions of January returns on first-quarter earnings using PY2006.

$$
R_{m 1, t}=a_{0}+a_{1} \frac{x_{q 1 t}}{P_{12 / 31 / t-1}}+a_{2} \frac{b_{q 4}}{P_{12 / 31 / t-1}}+\varepsilon_{t} \quad \text { Equation (22) }
$$

$\begin{array}{lccccc} & \mathbf{a}_{\mathbf{0}} & \mathbf{a}_{\mathbf{1}} & \mathbf{a}_{\mathbf{2}} & \text { Mean Adj. } \mathbf{R}^{\mathbf{2}} & \text { \# obs. } \\ \text { JE firms } & 0.218 * * * & -0.113 & -0.057^{\dagger} & 0.023 & 4,204 \\ \text { NJE firms } & -0.046 & -0.452 & 0.027 * * * & 0.047 & 2,974\end{array}$

* $\quad$ significant at $\alpha<0.05,1$-tail test

** significant at $\alpha<0.001,1$-tail test

$* * *$ significant at $\alpha<0.0001,1$-tail test

$\dagger$ p-value $<0.0001$ in a 1 -tail test of $a_{2}<0$ 
Table 14

Reverse regression analysis of the association of earnings with monthly components of contemporaneous annual returns. Values reported are mean coefficients of annual reverse regressions.

Quintile 1 firms.

Panel A Annual earnings and 12 months of the contemporaneous calendar year.

$$
\frac{x_{a, t}}{P_{12 / 31 / t-1}}=\phi_{0}+\sum_{\tau=1}^{12} \phi_{\tau} R_{m \tau}+\delta_{t}
$$

\begin{tabular}{|c|c|c|c|c|c|c|c|c|c|c|c|c|c|}
\hline $\begin{array}{l}\varphi_{0} \\
\text { (int) }\end{array}$ & $\begin{array}{l}\varphi_{1} \\
\text { (Jan) }\end{array}$ & $\begin{array}{l}\varphi_{2} \\
\text { (Feb) }\end{array}$ & $\begin{array}{l}\varphi_{3} \\
\text { (Mar) }\end{array}$ & $\begin{array}{l}\varphi_{4} \\
\text { (Apr) }\end{array}$ & $\begin{array}{l}\varphi_{5} \\
\text { (May) }\end{array}$ & $\begin{array}{l}\varphi_{6} \\
\text { (Jun) }\end{array}$ & $\begin{array}{l}\varphi_{7} \\
\text { (Jul) }\end{array}$ & $\begin{array}{l}\varphi_{8} \\
\text { (Aug) }\end{array}$ & $\begin{array}{l}\varphi_{9} \\
\text { (Sep) }\end{array}$ & $\begin{array}{l}\varphi_{10} \\
\text { (Oct) }\end{array}$ & $\begin{array}{l}\varphi_{11} \\
\text { (Nov) }\end{array}$ & $\begin{array}{l}\varphi_{12} \\
\text { (Dec) }\end{array}$ & $\mathbf{R}^{2}$ \\
\hline $0.046 *$ & 0.051 & $0.165 * * *$ & $0.178 * * *$ & $0.256 * * *$ & $0.185 * * *$ & $0.192 * * *$ & $0.240 * * *$ & $0.178 * * *$ & $0.178 * * *$ & $0.221 * * *$ & $0.178 * * *$ & $0.145 * * *$ & 0.207 \\
\hline
\end{tabular}




\section{Table 14, continued}

Panel B Quarterly earnings and the 3 months of the contemporaneous quarter.

$$
\begin{array}{ll}
\frac{x_{q 1, t}}{P_{12 / 31 / t-1}}=\phi_{0}+\phi_{1} R_{m 1, t}+\phi_{2} R_{m 2, t}+\phi_{3} R_{m 3, t}+\delta_{t} & \text { (Equation 27) } \\
\frac{x_{q 2, t}}{P_{03 / 31 / t}}=\phi_{0}+\phi_{4} R_{m 4, t}+\phi_{5} R_{m 5, t}+\phi_{6} R_{m 6, t}+\delta_{t} & \text { (Equation 28) } \\
\frac{x_{q 3, t}}{P_{06 / 30 / t}}=\phi_{0}+\phi_{7} R_{m 7, t}+\phi_{8} R_{m 8, t}+\phi_{9} R_{m 9, t}+\delta_{t} & \text { (Equation 29) } \\
\frac{x_{q 4, t}}{P_{09 / 30 / t}}=\phi_{0}+\phi_{10} R_{m 10, t}+\phi_{11} R_{m 11, t}+\phi_{12} R_{m 12, t}+\delta_{t} & \text { (Equation 30) }
\end{array}
$$

\begin{tabular}{|c|c|c|c|c|c|c|c|c|c|c|c|c|c|c|}
\hline Qtr. & $\begin{array}{l}\varphi_{0} \\
\text { (int) }\end{array}$ & $\begin{array}{l}\varphi_{1} \\
\text { (Jan) }\end{array}$ & $\begin{array}{l}\varphi_{2} \\
\text { (Feb) }\end{array}$ & $\begin{array}{l}\varphi_{3} \\
\text { (Mar) }\end{array}$ & $\begin{array}{l}\varphi_{4} \\
\text { (Apr) }\end{array}$ & $\begin{array}{l}\varphi_{5} \\
\text { (May) }\end{array}$ & $\begin{array}{l}\varphi_{6} \\
\text { (Jun) }\end{array}$ & $\begin{array}{l}\varphi_{7} \\
\text { (Jul) }\end{array}$ & $\begin{array}{l}\varphi_{8} \\
\text { (Aug) }\end{array}$ & $\begin{array}{l}\varphi_{9} \\
\text { (Sep) }\end{array}$ & $\begin{array}{l}\varphi_{10} \\
\text { (Oct) }\end{array}$ & $\begin{array}{l}\varphi_{11} \\
\text { (Nov) }\end{array}$ & $\begin{array}{l}\varphi_{12} \\
\text { (Dec) }\end{array}$ & $\mathbf{R}^{2}$ \\
\hline 1 & $0.008 * *$ & 0.007 & $0.036^{* * *}$ & $0.037 * * *$ & & & & & & & & & & 0.017 \\
\hline 2 & $0.014 * *$ & & & & $0.057 * * *$ & $0.038 * *$ & $0.043 * *$ & & & & & & & 0.030 \\
\hline 3 & $0.012 * *$ & & & & & & & $0.054 * * *$ & $0.052 * * *$ & $0.047 * * *$ & & & & 0.032 \\
\hline 4 & 0.006 & & & & & & & & & & $0.082 * * *$ & $0.079 * * *$ & $0.061 * *$ & 0.036 \\
\hline
\end{tabular}

* $\quad$ significant at $\alpha<0.05,2$-tail test

** significant at $\alpha<0.001,2$-tail test

$* * *$ significant at $\alpha<0.0001,2$-tail test 
Figures

Figure 1: Firm size and month effect, $1972-2005$

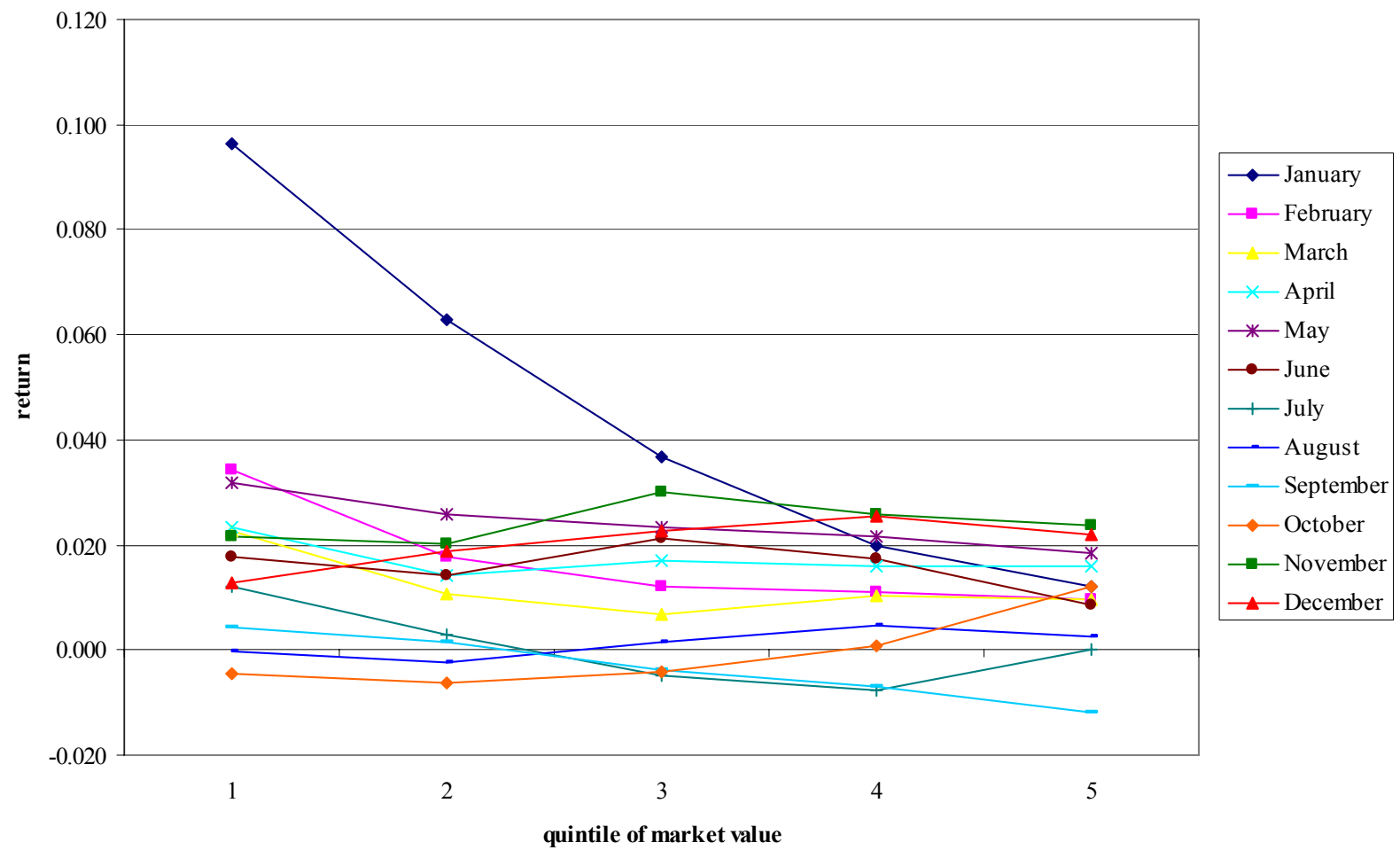


Figure 2: $\quad$ Time series of mean January returns for quintile 1 firms, $1972-2005$

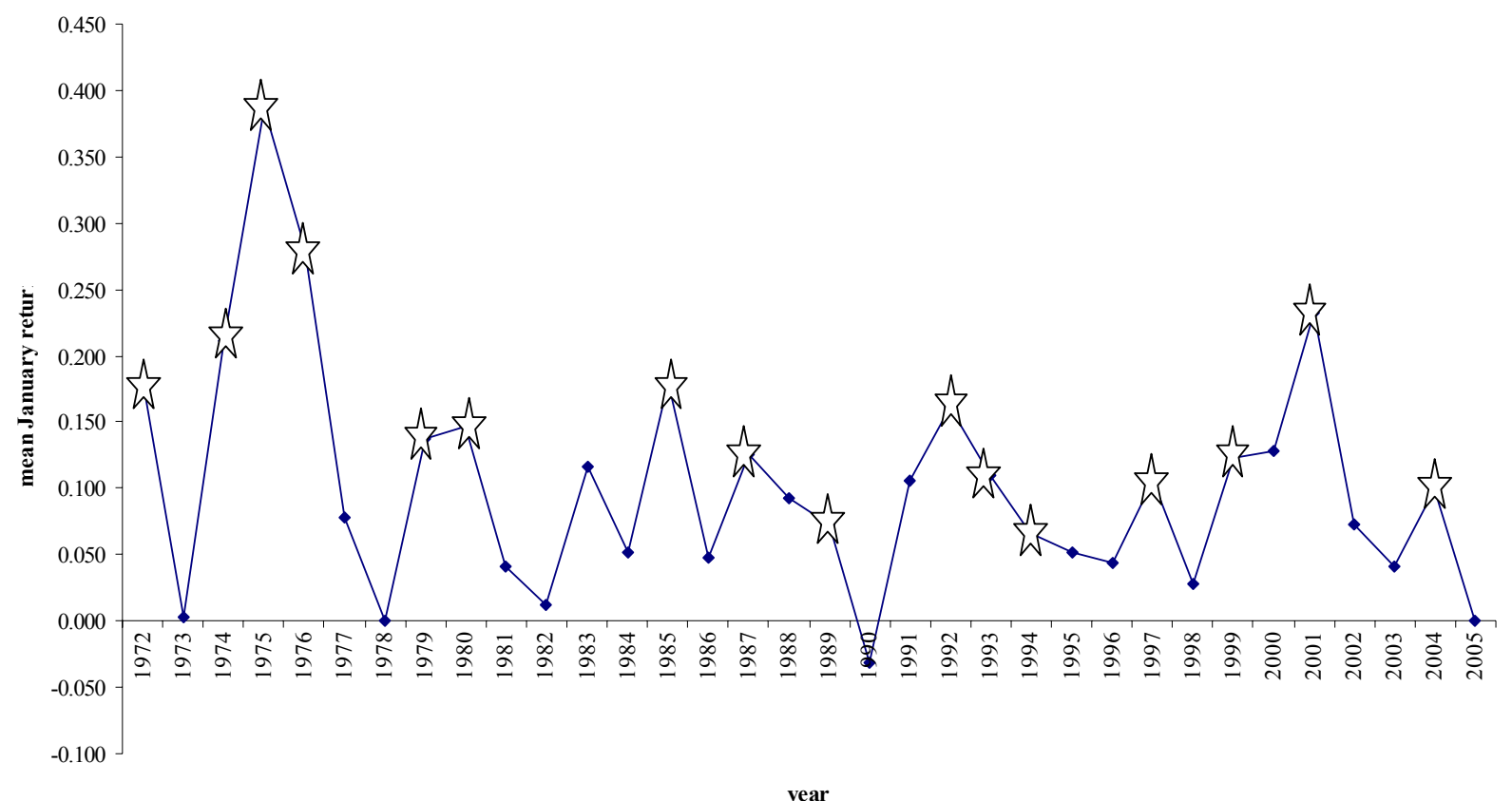

\footnotetext{
W indicates a "January effect" year, defined as a year in which January returns are higher than returns in any other month.
} 
Figure 3: Distribution of JE and NJE firms across 100 annual subsets of firm size ("percentiles").

Quintile 1 firms.

The graphs for quintiles 2 through 5 are similarly distributed.

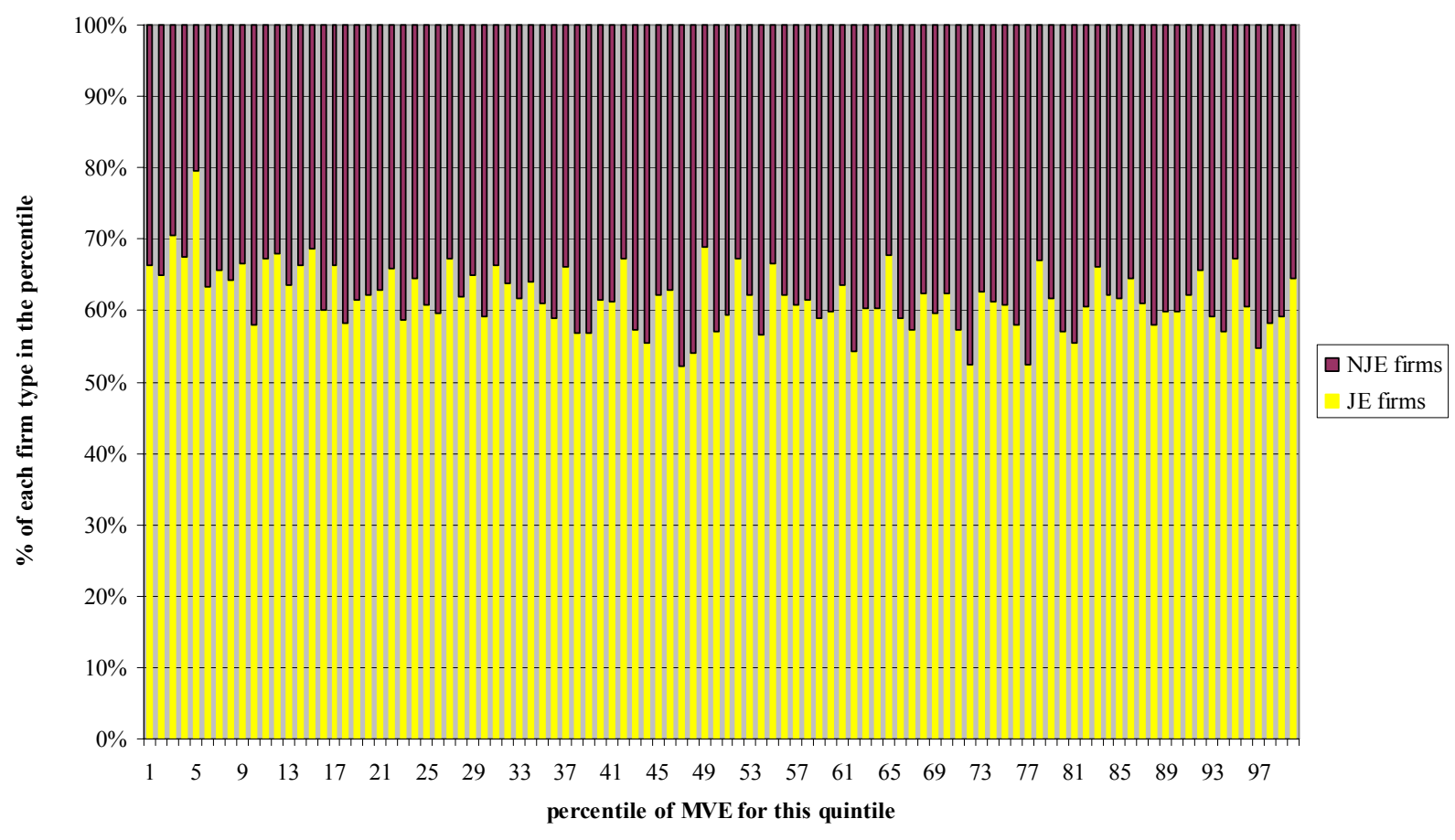




\section{Appendix A1}

\section{Derivation}

Starting with (3) and using [A3] to substitute for $v_{t}$,

$$
\begin{aligned}
P_{t} & =b_{t}+\alpha_{1} x_{t}^{a}+\alpha_{2}\left(\bar{x}_{t}^{a t+1}-\omega x_{t}^{a}\right) \\
& =b_{t}+\left(\alpha_{1}-\alpha_{2} \omega\right) x_{t}^{a}+\alpha_{2} \bar{x}_{t}^{a t+1}
\end{aligned}
$$

and differencing gives

$$
P_{t}-P_{t-1}=\left(b_{t}-b_{t-1}\right)+\left(\alpha_{1}-\alpha_{2} \omega\right)\left(x_{t}^{a}-x_{t-1}^{a}\right)+\alpha_{2}\left(\bar{x}_{t}^{a t+1}-\bar{x}_{t-1}^{a t}\right) .
$$

From the definition of abnormal earnings (Ohlson 2001, p.109),

$$
x_{t}^{a}-x_{t-1}^{a}=\left(x_{t}-r b_{t}\right)-\left(x_{t-1}-r b_{t-1}\right)=\left(x_{t}-x_{t-1}\right)-r\left(b_{t}-b_{t-1}\right) \text {. Substituting this expression for }
$$

the difference in abnormal earnings in the second term of (A1.2),

$$
P_{t}-P_{t-1}=\left(b_{t}-b_{t-1}\right)+\left(\alpha_{1}-\alpha_{2} \omega\right)\left[\left(x_{t}-x_{t-1}\right)-r\left(b_{t}-b_{t-1}\right)\right]+\alpha_{2}\left(\bar{x}_{t}^{a t+1}-\bar{x}_{t-1}^{a t}\right) .
$$

Applying the clean surplus accounting relation, change in book value is characterized as earnings less dividends:

$$
b_{t}-b_{t-1}=x_{t}-d_{t}
$$

Substituting the definition of abnormal earnings into the last term of (A1.3) and factoring out the common term $x_{t}-d_{t}$ results in

$$
P_{t}-P_{t-1}=\left[1-r\left(\alpha_{1}-\alpha_{2} \omega\right)-r \alpha_{2}\right]\left(x_{t}-d_{t}\right)+\left(\alpha_{1}-\alpha_{2} \omega\right)\left(x_{t}-x_{t-1}\right)+\alpha_{2}\left(\bar{x}_{t}^{t+1}-\bar{x}_{t-1}^{t}\right) .
$$


Using the notation of Ohlson (2001), let $\lambda=\frac{r+1-\omega \gamma}{(r+1-\omega)(r+1-\gamma)}=\alpha_{1}-\alpha_{2}(\omega-1)$. Then the first term in (A1.4) can be simplified to $(1-r \lambda)\left(x_{t}-d_{t}\right)$. Splitting apart the earnings and dividend terms, rearranging and dividing the entire expression through by $P_{t-1}$ yields

$$
\frac{P_{t}-P_{t-1}+d_{t}}{P_{t-1}}=(1-r \lambda) \frac{x_{t}}{P_{t-1}}+\left(\alpha_{1}-\alpha_{2} \omega\right) \frac{x_{t}-x_{t-1}}{P_{t-1}}+\alpha_{2} \frac{\bar{x}_{t}^{t+1}-\bar{x}_{t-1}^{t}}{P_{t-1}}+r \lambda \frac{d_{t}}{P_{t-1}}
$$

The first term on the right hand side of (A1.5) is earnings level. The second term is change in earnings. The third term is change in expectation for future earnings - which can be operationalized as change in analysts' forecasts. The fourth term, $r \lambda \frac{d_{t}}{P_{t-1}}$, represents a valuation adjustment to forecasts of future earnings caused by payout of current dividends. As a practical matter, this term also may be thought of as bias or measurement error in the dependent variable which is captured in the intercept of a linear regression equation. 


\section{Appendix A2}

Rearranging A1.2,

$$
P_{t}-b_{t}=\left(P_{t-1}-b_{t-1}\right)+\left(\alpha_{1}-\alpha_{2} \omega\right)\left(x_{t}^{a}-x_{t-1}^{a}\right)+\alpha_{2}\left(\bar{x}_{t}^{a t+1}-\bar{x}_{t-1}^{a t}\right)
$$

From the definition of abnormal earnings (Ohlson 2001, p.109),

$$
x_{t}^{a}-x_{t-1}^{a}=\left(x_{t}-r b_{t}\right)-\left(x_{t-1}-r b_{t-1}\right)=\left(x_{t}-x_{t-1}\right)-r\left(b_{t}-b_{t-1}\right) \text {. Substituting into the second and }
$$

third terms of (A2.1) and applying CSR yields

$$
P_{t}-b_{t}=\left(P_{t-1}-b_{t-1}\right)+\left(\alpha_{1}-\alpha_{2} \omega\right)\left[\left(x_{t}-x_{t-1}\right)-r\left(x_{t}-d_{t}\right)\right]+\alpha_{2}\left\lfloor\bar{x}_{t}^{t+1}-\bar{x}_{t-1}^{t}-r\left(x_{t}-d_{t}\right)\right\rfloor \text {. }
$$

Factoring and rearranging,

$$
P_{t}-b_{t}=\left(P_{t-1}-b_{t-1}\right)+\left(\alpha_{1}-\alpha_{2} \omega\right)\left(x_{t}-x_{t-1}\right)+\left[\alpha_{2}(\omega-1)-\alpha_{1}\right]\left[r\left(x_{t}-d_{t}\right)\right]+\alpha_{2}\left(\bar{x}_{t}^{t+1}-\bar{x}_{t-1}^{t}\right) .
$$

Thus, Penman and Yehuda (2006) show that current premium to book value equals the previous premium adjusted for change in earnings, the reduction in current book value due to dividend payments and change in forecast for future earnings. As a simple intuitive example suppose that the previous premium, $P_{t-1}-b_{t-1}$ is equal to zero. That is, at time $t-1$ price was exactly equal to book value. Then any difference between price and book value at time $t$ must be due to change in earnings from the previous period, dividends paid during the period and change in forecast for next period earnings. 


\section{Appendix A3}

Assume that a $\theta_{i}$ coefficient from the annual Fama-MacBeth regressions exhibits first-order autocorrelation $\alpha$. Then the OLS standard error is understated. The true variance of the sum of $\mathrm{N}$ observations of $\theta_{i}$ is given by

$$
\sigma^{2}\left(\sum_{t=1}^{N} \theta_{i, t}\right) \cong N \sigma^{2}\left(\theta_{i}\right)\left[\frac{1+\alpha}{1-\alpha}\right]
$$

when $\mathrm{N}$ is sufficiently large. Thus, the standard error of the mean when $\theta_{i}$ exhibits autocorrelation of $\alpha$ is actually $\sqrt{\frac{1+\alpha}{1-\alpha}}$ higher than OLS estimate. 


\section{References}

Ali, Ashiq, and Paul Zarowin. 1992. The role of earnings levels in annual earnings-returns studies. Journal of Accounting Research 30 (2):286-296.

Ball, Ray, and Philip Brown. 1968. An empirical evaluation of accounting income numbers. Journal of Accounting Research 6 (2):159-177.

Beaver, William H. 1968. The information content of annual earnings announcements. Journal of Accounting Research 6 (3 (Supplement: Empirical Research in Accounting)):67-92. . 2002. Perspectives on recent capital market research. The Accounting Review 77 (2):453-474.

Beaver, William H., Richard A. Lambert, and Dale Morse. 1980. The information content of security prices. Journal of Accounting and Economics 2 (1):3-28.

Beaver, William H., Richard A. Lambert, and Stephen G. Ryan. 1987. The information content of security prices: a second look. Journal of Accounting and Economics 9 (2):139-157.

Beaver, William H., and Dale Morse. 1978. What determines price-earnings ratios? Financial Analysts Journal 34 (4):65-76.

Bernard, Victor L., and Jacob K. Thomas. 1989. Post-earnings announcement drift: delayed price response or risk premium? Journal of Accounting Research 27 (3):1-36.

Bhushan, Ravi. 1989. Firm characteristics and analyst following. Journal of Accounting and Economics 11 (2/3):255-274.

Branch, Ben. 1977. A tax loss trading rule. Journal of Business 50 (2):198-207.

Brown, Lawrence D. 1993. Earnings forecasting research: its implications for capital markets research. International Journal of Forecasting 9:295-320.

Brown, Lawrence D., and Liyu Luo. 2006. The January barometer: further evidence. The Journal of Investing 15 (1):25-31.

Brown, Lawrence D., and Michael S. Rozeff. 1978. The superiority of analyst forecasts as measures of expectations: evidence from earnings. The Journal of Finance 33 (1):1-16.

Brown, Philip, Donald B. Keim, Allan W. Kleidon, and Terry A. Marsh. 1983. Stock return seasonalities and the tax-loss selling hypothesis: analysis of the arguments and Australian evidence. Journal of Financial Economics 12 (1):105-127.

Burgstahler, David C., and Ilia Dichev. 1997. Earnings, adaptation and equity value. The Accounting Review 72 (2):187-215.

Christie, Andrew A. 1987. On cross-sectional analysis in accounting research. Journal of Accounting and Economics 9 (3):231-258.

Collins, Daniel W., and S.P. Kothari. 1989. An analysis of intertemporal and cross-sectional determinants of earnings response coefficients. Journal of Accounting and Economics 11 (2/3):143-181.

Collins, Daniel W., S.P. Kothari, and Judy Dawson Rayburn. 1987. Firm size and the information content of prices with respect to earnings. Journal of Accounting and Economics 9 (2):111-138.

Dempsey, Stephen J. 1989. Predisclosure information search incentives, analyst following, and earnings announcement price response. The Accounting Review 64 (4):748-757.

Dyl, Edward A. 1977. Capital gains taxation and year-end stock market behavior. The Journal of Finance 32 (1):165-175.

Eakins, Stan, and Susan Sewell. 1993. Tax-loss selling, institutional investors, and the January effect: a note. Journal of Financial Research 16 (4):377-384. 
Easterday, Kathryn E., Pradyot K. Sen, and Jens A. Stephan. 2007. The Small Firm/January Effect: Is it Disappearing in U.S. Markets Because of Investor Learning?: University of Cincinnati working paper, SSRN: $\underline{\text { htp: } / / \text { ssrn.com/abstract }=996413 .}$

Easton, Peter D. 1999. Security returns and the value relevance of accounting data. Accounting Horizons 13 (4):399-412.

Easton, Peter D., and Trevor S. Harris. 1991. Earnings as an explanatory variable for returns. Journal of Accounting Research 29 (1):19-36.

Easton, Peter D., Trevor S. Harris, and James A. Ohlson. 1992. Aggregate accounting earnings can explain most of security returns. Journal of Accounting and Economics 15:119-142.

Easton, Peter D., and Mark E. Zmijewski. 1989. Cross-sectional variation in the stock market response to accounting earnings announcements. Journal of Accounting and Economics $11(2 / 3): 117-141$.

Elliott, John A., and J. Douglas Hanna. 1996. Repeated accounting write-offs and the information content of earnings. Journal of Accounting Research 34 (3):135-155.

Fama, Eugene F. 1991. Efficient capital markets: II. The Journal of Finance 46 (5):1575-1617.

-1998. Market efficiency, long-term returns, and behavioral finance. Journal of Financial Economics 49 (3):283-306.

Fama, Eugene F., Lawrence Fisher, Michael C. Jensen, and Richard Roll. 1969. The adjustment of stock prices to new information. International Economic Review 10 (1):1-21.

Fama, Eugene F., and Kenneth R. French. 1992. The cross-section of expected stock returns. The Journal of Finance 47 (2):427-465.

- 2002. Testing trade-off and pecking order predictions about dividends and debt. The Review of Financial Studies 15 (1):1-33.

Fama, Eugene F., and James D. MacBeth. 1973. Risk, return, and equilibrium: empirical tests. Journal of Political Economy 81 (3):607-636.

Feltham, Gerald A., and James A. Ohlson. 1995. Valuation and clean surplus accounting for operating and financial activities. Contemporary Accounting Research 11 (2):689-731.

Foster, George. 1977. Quarterly accounting data: time-series properties and predictive-ability results. The Accounting Review 52 (1):1-21.

Fountas, Stilianos, and Konstantinos N. Segredakis. 2002. Emerging stock markets returns seasonalities: the January effect and the tax-loss selling hypothesis. Applied Financial Economics 12 (4):291-300.

Francis, Jennifer, Donald Pagach, and Jens A. Stephan. 1992. The stock market response to earnings announcements released during trading versus nontrading periods. Journal of Accounting Research 30 (2):165-184.

Freeman, Robert N. 1987. The association between accounting earnings and security returns for large and small firms. Journal of Accounting and Economics 9 (2):195-228.

Grinblatt, Mark, and Matt Keloharju. 2004. Tax-loss trading and wash sales. Journal of Financial Economics 71 (1):51-75.

$\mathrm{Gu}$, Anthony Yanxiang. 2003. The declining January effect: evidences from the U.S. equity markets. The Quarterly Review of Economics and Finance 43:395-404.

Haug, Mark, and Mark Hirschey. 2006. The January Effect. Financial Analysts Journal 62 (5):78-88.

Haugen, Robert A., and Philippe Jorion. 1996. The January effect: still there after all these years. Financial Analysts Journal 52 (1):27-31. 
Hayn, Carla. 1995. The information content of losses. Journal of Accounting and Economics 20 (2):125-153.

Jones, Steven L., Winson Lee, and Rudolf Apenbrink. 1991. New evidence on the January effect before personal income taxes. The Journal of Finance 46 (5):1909-1924.

Joseph, George, and Roland Lipka. 2006. Distressed firms and the secular deterioration in usefulness of accounting information. Journal of Business Research 59 (2):295-303.

Keim, Donald B. 1983. Size-related anomalies and stock return seasonality: further empirical evidence. Journal of Financial Economics 12:13-32.

Kothari, S.P. 2001. Capital markets research in accounting. Journal of Accounting and Economics 31 (1-3):105-231.

Kothari, S.P., and Richard G. Sloan. 1992. Information in prices about future earnings: implications for earnings response coefficients. Journal of Accounting and Economics 15 (2-3):143-171.

Kramer, Charles. 1994. Macroeconomic seasonality and the January effect. The Journal of Finance 49 (5):1883-1891.

Kross, William J., and Douglas Schroeder. 1990. An investigation of seasonality in stock prices to quarterly earnings announcements. Journal of Business Finance \& Accounting 17 (5):649-675.

Ligon, James A. 1997. A simultaneous test of competing theories regarding the January effect. The Journal of Financial Research 20 (1):13-32.

Lu, Hai, and Qingzhong Ma. 2003. Do earnings explain the January effect?: University of Southern California working paper, SSRN: http://ssrn.com/abstract=479141.

McConnell, John J., Alexei V. Ovtchinnikov, and Michael Cooper. 2005. The other January effect: AFA 2006 Boston Meetings paper, SSRN: http://ssrn.com/abstract=663563.

Mehdian, Seyed, and Mark J. Perry. 2002. Anomalies in US equity markets: A re-examination of the January effect. Applied Financial Economics 12 (2):141-145.

O'Brien, Patricia C. 1988. Analysts' forecasts as earnings expectations. Journal of Accounting and Economics 10 (1):53-83.

Ohlson, James A. 1995. Earnings, book values, and dividends in equity valuation. Contemporary Accounting Research 11 (2):661-687.

- 2001. Earnings, book values and dividends in equity valuation: an empirical perspective. Contemporary Accounting Research 18 (1):107-120.

Ohlson, James A., and Beate E. Juettner-Nauroth. 2005. Expected EPS and EPS growth as determinants of value. Review of Accounting Studies 10 (2-3):349-365.

Ohlson, James A., and Pervin K. Shroff. 1992. Changes versus levels in earnings as explanatory variables for returns: some theoretical considerations. Journal of Accounting Research 30 (2):210-226.

Patell, James M., and Mark A. Wolfson. 1984. The intraday speed of adjustment of stock prices to earnings and dividend announcements. Journal of Financial Economics 13 (2):223252.

Penman, Stephen H. 1987. The distribution of earnings news over time and seasonalities in aggregate stock returns. Journal of Financial Economics 18 (2):199-228.

Penman, Stephen H., and Theodore Sougiannis. 1998. A comparison of dividend, cash flow, and earnings approaches to equity valuation. Contemporary Accounting Research 15 (3):343383. 
Penman, Stephen H., and Nir Yehuda. 2006. The pricing of earnings and cash flows and an affirmation of accrual accounting: working paper (Columbia University).

Petersen, Mitchell A. 2006. Estimating standard errors in finance panel data sets: comparing approaches: Kellogg School of Management, Northwestern University and NBER.

Poterba, James M., and Scott J. Weisbenner. 2001. Capital gains tax rules, tax-loss trading, and turn-of-the-year returns. The Journal of Finance 56 (1):353-368.

Reinganum, Marc R. 1983. The anomalous stock market behavior of small firms in January. Journal of Financial Economics 12 (1):89-104.

Ritter, Jay R. 1988. The buying and selling behavior of individual investors at the turn of the year. The Journal of Finance 43 (3):701-717.

Ritter, Jay R., and Navin Chopra. 1989. Portfolio rebalancing and the turn-of-the-year effect. The Journal of Finance 44 (1):149-166.

Rozeff, Michael S. 1983. Predicting long-term earnings growth: comparisons of expected return models, submartingales and Value Line analysts. Journal of Forecasting 2:425-435.

Rozeff, Michael S., and Jr. Kinney, William R. 1976. Capital market seasonality: the case of stock returns. Journal of Financial Economics 3 (4):379-402.

Ryan, Stephen G. 1986. Structural models of the price to earnings relation: measurement errors in accounting earnings. Palo Alto, CA: Stanford University.

- 1988. Structural models of the accounting process and earnings. Dissertation, Stanford University, Palo Alto, CA.

Schwert, G. William. 2003. Anomalies and market efficiency. In Handbook of the Economics of Finance, edited by G. Constantinides, M. Harris and R. Stulz. Amsterdam, Boston: Elsevier/North-Holland.

Sias, Richard W., and Laura T. Starks. 1997. Institutions and individuals at the turn of the year. The Journal of Finance 52 (4):1543-1562.

Wachtel, Sidney B. 1942. Certain observations on seasonal movements in stock prices. Journal of Business 15 (2):184-193.

Warfield, Terry D., and John J. Wild. 1992. Accounting recognition and the relevance of earnings as an explanatory variable for returns. The Accounting Review 67 (4):821-842. 